LA- $-9513-I H S$

UC-70

DE83 003895

Issued: September 1982

\title{
Los Alamos DP West Plutonium Facility Decontamination Project, 1978- 1981
}

Raymond Garde

E. J. Cox

Allen M. Valentine

\section{NOTICE}

PORTIONS OF THIS REPORT ARE ILLEGIBLE. It

has been reproduced from the best available copy to permit the broadest possible availability.





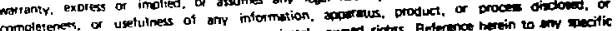

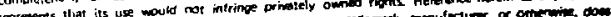

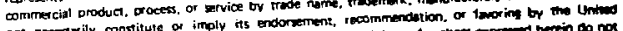

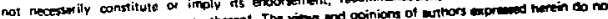




LOS ALAMOS DP WEST PLUTONIUM FACILITY DECONTAMINATION PROJECT $1978-1981$

by

Raymond Garde, E. J. Cox, and Allen M. Valentine

ABSTRACT

The DP West Plutonlum Facllity operated by the Los Alamos National Laboratory, Los Alamos. New Mexico was decontaminated oetween April 1978 and April 1981. The facility was constructed in 1944-45 to produce plutonium metal and fabricate parts for nuclear weapons. It was continually used as a plutonium processing and research facility until mid-1978.

Decontamination operations included dismantling and removing gloveboxes and conveyor tunnels; removing process systems, utilities, and exhaust ducts: and decontaminating all remaining surfaces. This report describes glovebox and conveyor tunnel separations, decontamination techniques, health and safety considerations, waste management procedures, and costs of the operation.

\section{INTRODUCTION}

The Plutonium Facility at DP West Site designated as Technical Area $21(\mathrm{TA}-21)$ at the Los Al amos National Laboratory, Los Alamos, New Mexico (Fig. 1) was decontaminated during the period from April 1978 to April 1981. The overall objective was to decontaminate three entire buildings and portions of three others, a total of $5330 \mathrm{~m}^{2}$ of floor space, to a level which would allow continued occupancy for nonplutoni un research operations.

Major elements of the decontamination project included :

- removal of process related service systems, utilities, and exhaust systems;

- preliminary experimental decontamination of plutonium contaminated gloveboxes ;

- separation and packaging of 318 linear meters of gloveboxes and 109 linear meters of connecting conveyor tunnels;

- Hecontamination of $3500 \mathrm{~m}^{2}$ of concrete floors and $30,000 \mathrm{~m}^{2}$ of walls and ceilings;

- development of techniques to measure residual plutonium levels through various surface coatings and materials; and

- radiation surveys of decontaminated surfaces and equipment items.
Before commencing the decontamination operation, a general plan was formulated which was submitted to the Albuquer que Area Operations office of the US Department of Energy (DOE) for approval.

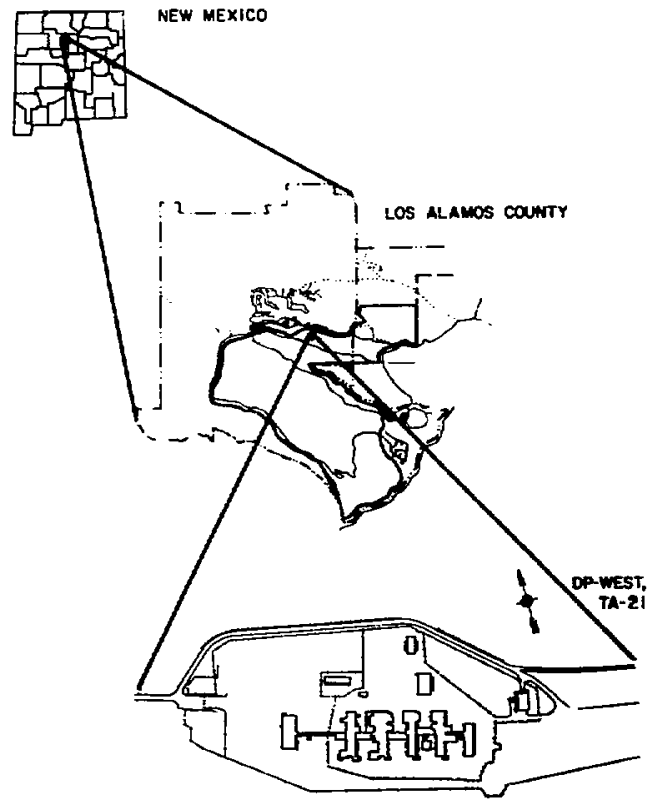

Fig. 1. Technical Area 21, Los Almos, New Hexico. 
The approved final management plan ${ }^{9}$ established that:

- the operation would be limited to Buildings 2, 3, 4, 5, 150, and 286 (Fig. 2);

o high-activity liquid wastes would be reprocessed rather than discarded;

- decontanination criteria would be (1) no swipeable surface contamination, (2) fixed contamination not to exceed $1000 \mathrm{dis} / \mathrm{min} /$ $100 \mathrm{~cm}^{2}$ alpha, or $1 \mathrm{mR} / \mathrm{h}$ beta-gamma at contact when measured with an open-shield Gelger-Muller (GM) detector:

- decontamination operations would include (1) removal of all process equipment such as gloveboxes, pumps, storage tanks, etc: (2) removal of contaminated support process equipment such as piping, ventilation ductwork, and drain lines only to the point where they exited the area being decontaminated; (3) removal of internally contaminated lines, ducts, etc., in areas such as utility tunnels or attics; (4) removal of walls, cellings, and floors with contamination in excess of recommended levels; (5) installation of a new floor cover and repairiting of all decontaminated wall and ceiling surfaces prior to release of an area; (6) removal of the industrial waste sampling stations and wells; (7) disconnection of all services in the perimeter tunnels; and (8) documentation of final remaining surface contamination:

- solid wastes generated by the operation would be disposed of or stored at an onsite radioactive waste management site, TA-54, after being packaged according to current Los Alamos criteria. ${ }^{2}$ TA-54 is located $15 \mathrm{~km}$ from DP west.

A Los Al amos management team was formed with representatives from the plutonion Chemistry and Metallurgy group ( CMB-11), the Health Physics Group (H-1), and the Engineering Construction group (ENG-1).

Group CMB-11 was assigned the overall management because the decontamination of $T A-21$ was considered to be the final step in the new plutonium facility (TA-55) construction project. The 4.46 million dollars allocated for the decontamination were part of the line-item construction funds for TA-55. The group also provided the project manager and part-time support from individuals knowledgeable about each room or process.

Group $\mathrm{H}-1$ contributed experienced decontanination personnel who performed glovebox removal operations and directed subsequent decontamination work as weil as the personnel required to provide health physics support.

Group ENG-1 provided an engineer to assist in planning the project and to coordinate the craft and equipment support required of the 21 a company, the DOE's maintenance contractor at los Alamos. The 21 a Company assigned a full-time field engineer to work with the management team and to direct work performed by zia Company personnel.

A Health Division Task Force was created to ensure that all aspects of health and safety were considered. Disciplines represented on the task force were health physics, safety, industrial hygiene, waste management, and environmental surveillance.

Weekly management team meetings were held to discuss progress and to schedule work assigments for the following month.

\section{HISTORY OF DP SITE}

The DP Site Plutonium Facilities replaced the original D Building Plutonium Facility in the Los Alamos Technical Area (TA-1). Most of the facilities were constructed in 1944..1945 by moving in used warehouses and installing necessary equipment (Fig. 3).

Basically, the facility provided the capability to produce metal and alloys of plutonium and other transuranic elements from nitrate solution feed stock; to fabricate these netals into prec1sion shapes; to provide and install protective claddings; to measure the chemical and physical properties of these metals and alloys: and te permit recycling of scrap or materials used in experiments so that these materials could be reused rather than discarded.

Aditional safety and effluent treatment reatures were soon required as control systems and safety standards changed. Some of the aujor changes or additions between the evolution and retirement of the site were the following. 


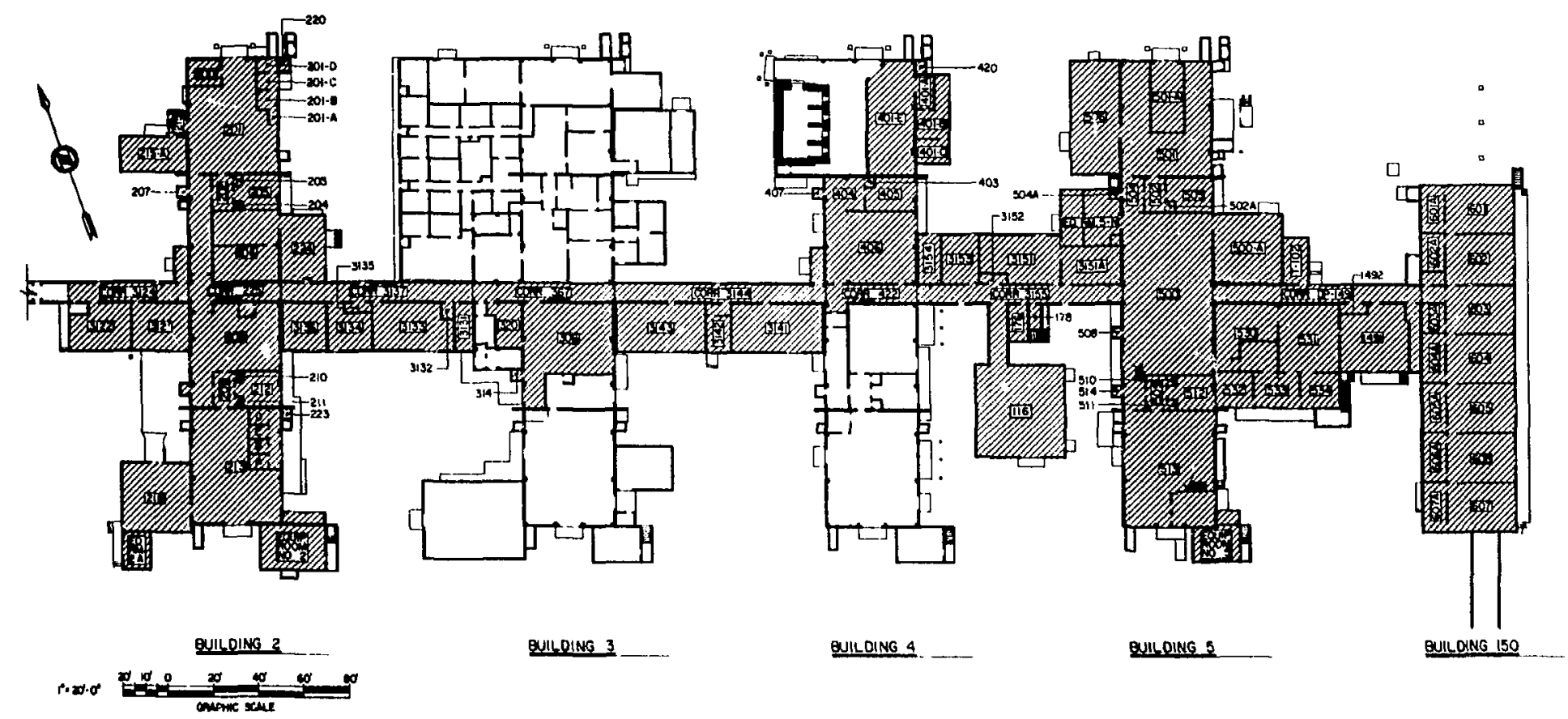

FiB. 2. DP West main plant; shaded areas in project scope. 


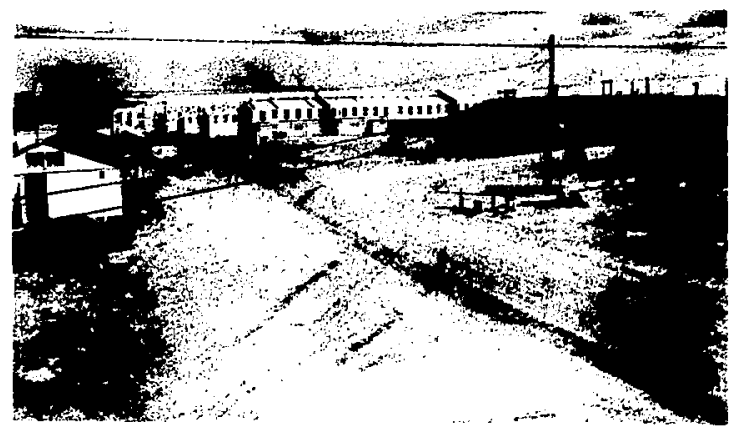

Fig. 3. TA-21, DP Hest, 1947.

- In 1949, plutoniun gloveboxes were connected with short pass-through tunnels.

- In 1951, a semi-automated metal production line was put into operation. A facility was completed for recovering plutonium in dilute residues. Secondary containment rooms were constructed around potentially hazardous operations.

- In 1952, a l1quid waste treatment plant was constructed. This treatment plant, structure TA-21-35, was replaced by a new treatment plant. TA-21-257 and was decommissioned in 1968.

- In 1956, the plutonlum metallurgical and metal fabrication systens were rebuilt. Conveyor tunnel systems were placed above the gloveboxes, allowing inproved plutonium transfer capabilities and personnel passage under the tunnels.

- In 1959, a nuclear critical1ty alarm systen based on detection of $\mathrm{B}$ and radiation was Installed. The process exhaust system was separated from the plant exhaust system. The new system included a high-efriciency filtration system located in Building TA-2 1-146.

- In 1963, new plutonilu fuels development building (Building TA-21-150) wa constructed.

- In 1967, a new I1quid waste treatment plant (TA-21-257) was constructed.
- In 1968, personnel corridors between major bufldings were converted to ventilated air locks.

- In 1971, new room exhaust air systems were installed in plutonium areas and vitily services were upgraded.

- In 1973, the exhaust filter building (TA-21-12), abandoned in 1959, was decommissioned. 3

- In 1974, a wet pipe sprinkler system was Installed throughout the plutonium processing buildings.

- In 1977. the transfer of equipment to the new TA-55 Plutoni un Facllity began.

- In 1981, decontamination was completed and the areas were transferred to new tenants (F1g. 4).

Because the first structures, Buildings 2, 3. 4, and 5, were prefabricated warehouses, they were placed on $1.1-\mathrm{m}$ high concrete stem walls to provide the necessary overhead space inside the rooms. A typical wall section for these buildings is shown in Fig. 5. In some roons, mezzanines were constructed to provide more floor space. Metal jolsts. metal decking, metal lath, and plaster were used for floors and ceilings in these areas.

Buildig 150 construction is unique to the rest of the process facilities. The building is primarily concrete and masonry with metal joists. It has a full basenent which housed most of the process support equipment and service piping. $h$ cross section of a Bullding 150 wall is show in Fig. 6 .

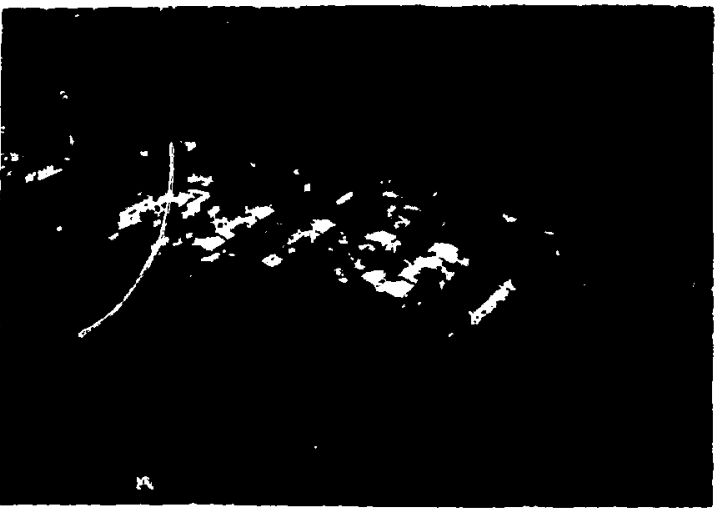

F18. 4. Th-21, DP weat after decontemination, 1981. 


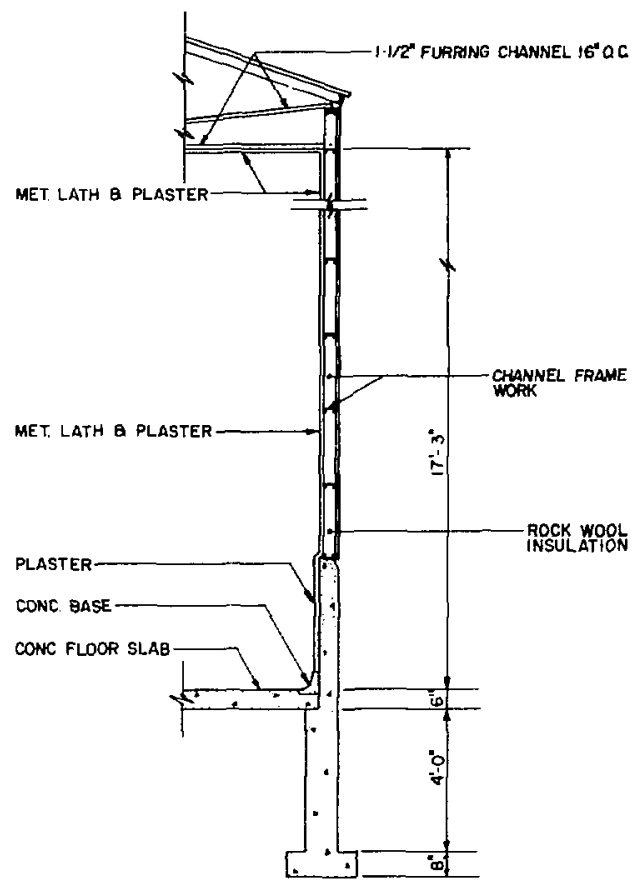

TYPICAL WALL SECTION BUILDINGS $2,3,485$ SCALE $3 / 8^{\circ}=1 \cdot 0^{\circ}$

Fig. 5. Typical wall section, Buildings $2,3,4$, and 5 .

III. PAELIMINARY INVESTIGATIONS

A. Glovebox Decontamination

Early in the planning of the operation, it became apparent that perhaps the most difficult task would be the safe removal and disposal/storage of the gloveboxes and conveyor systems used for plutonium processing.

Consideration was given to decontaminating the gloveboxes to a level that would permit nonretrievable shallow trench disposal rather than the more costly 20-year storage required for transuranic (TRU) waste contaminated to levels greater than $10 \mathrm{nCi}{ }^{239} \mathrm{Pu}$ or $100 \mathrm{nCi}{ }^{238} \mathrm{Pu}$ per gram of waste. If successful, decontaminating the gloveboxes in place would provide additional benefits in that the boxes would be safer to separate and the lower plutonium levels wold facilitate future size reduction. However, the acld wash solutions used for the decontamination operation would require neutralization, solidification, and disposal/storage.

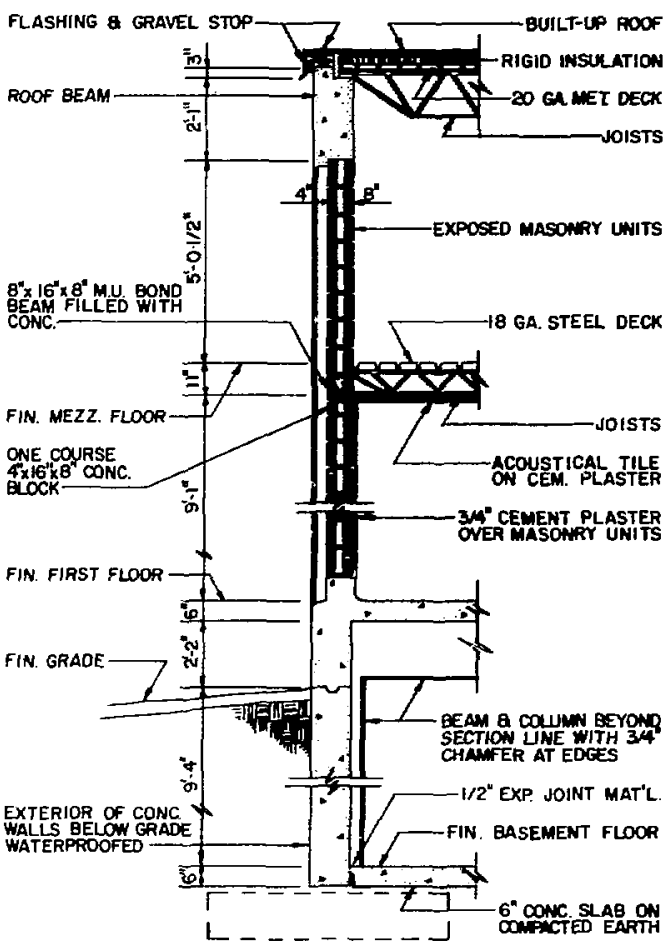

TYPICAL WALL SECTION BUILDING 150 SCALE $3 / 8^{\circ}=i^{\prime}-0^{\circ}$

Fig. 6. Typical wall section, Building 150.

Washing would also be a slow and hazardous process. The equipment used for the washing is show in Fig. 7 .

The first 20 gloveboxes available for experimental decontamination were subjected to numerous wash-rinse cycles (Appendix A). Between cycles, the plutonium ievels remaining in the box were measured by NaI surveys and the change in measured plutonium content was compared to the quantity of plutonium measured in the wash-rinse solution. Some of the information gained from washing operations includes:

- one acid wash-water rinse cycle removed approximately $85 \%$ of the plutonium in the gloveboxes;

- the plutonium content in a glovebox that had been wet wiped but had not been washed would likely contain nine times more plutonium than initially measured by WaI surveys due to contamination hidden in cracks, 


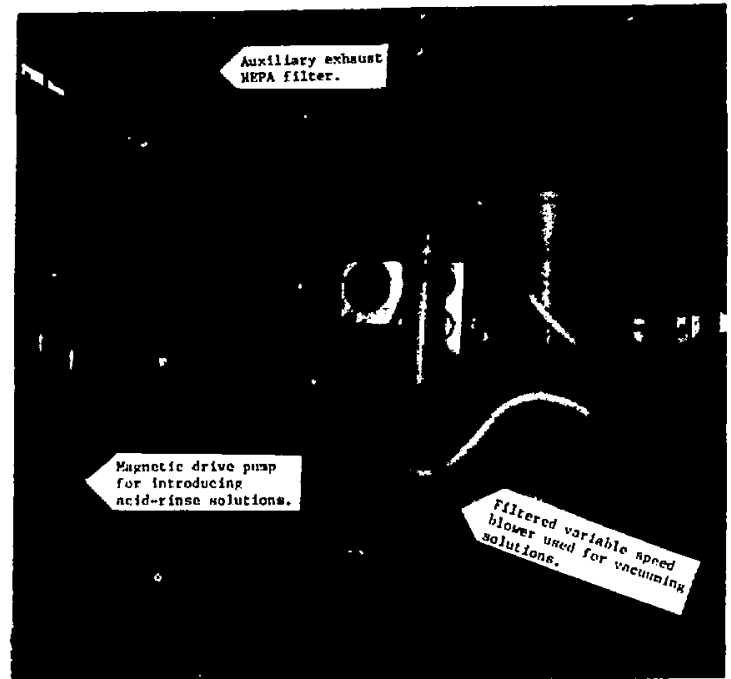

Fig. 7. Glovebox washing and vacuming apparatus.

corners, and other shielded locations. If a glovebox was washed before being surveyed, the difference between the measured and actual plutonium amounts was a factor of five with the actual being the higher:

- the plutonium content of most gloveboxes could be measured by taking readings through gloveports using new 25-mil unleaded gloves (Appendix B); and

- surveys indicated glovebox contamination levels could be reduced to a nonretrievable level by numerous wash cycles, but due to the large solution volumes, the work should be performed in a well-equipped decontamination facility with proper waste handling and ventilation systems.

The efforts required in decontaminating the 20 gloveboxes indicated that the decontamination project funding and schedule would not permit washing gloveboxes to nonretrievable levels. The decision was made to proceed with glovebox removal and storage as retrievable TRU waste.

\section{B. Glovebox Separations}

Another early concern about glovebox removal was that separating the individual gloveboxes would be difficult because several boxes were large and in some cases working space was 1 imited. Portable collapsible plywood and plastic tent enclosures with air locks were used on the first glovebox separation. Careful planning and thorough instruction of each member of the glovebox separation team resulted in such a successful operation that use of the air lock and tent was eliminated for the remaining 120 glowebox and 16 conveyor tunnel separations (Fig. 8).

\section{Containation History}

During the early stages of the operation, past records were searched extensively to identify all potential residual contamination sources and locations. Health Physics survey and occurrence records dating back to 1945 were removed from the archives and reviewed. Lists of recorded spills or releases of contamination were complled for each room. This information was very useful in deciding whether to remove internal walls, floors, building utilities, and soll.

\section{PROJECT DESCRIPTION}

Decontamination operations performed during this project were directed by experienced Individuals from the Laboratory's Decontamination and Decomissioning Section based in the Health Physics Group. Tnese four to five supervisors and techn1cians had years of experience in equipment and facility decontamination involving plutonium. Because only these few experienced individuals were avallable for assigment to this project, some six

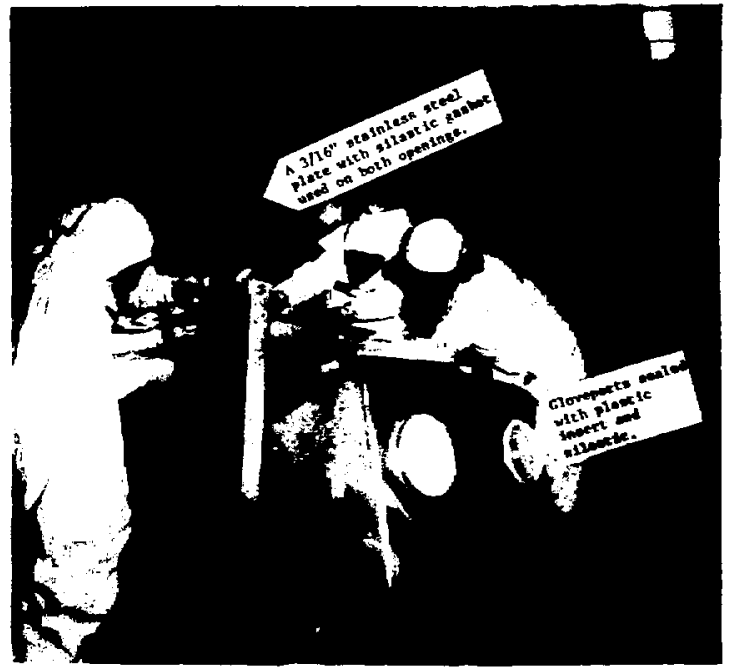

Fig. 8. Glovebox-conveyor tumnel separations. 
to eight additional. inexperienced technicians were hired to assist with desontamination operations.

A full-scale startup during early phases of the operation was precluded until the process-byprocess transfer of operations to the new plutonium facility was complete. Building utilities were completely operational during this period, even though much of the system was not being used. For the first several months personnel worked in gloveboxes and portions of various 1 solated rooms as they became avallable.

As soon as all areas were available, the General plan was 1 mplemented and the decontamination and release of areas in an east-to-west direction began. This plan allowed systematic access control to rooms and building areas with a well-defined contaminated-area/clean-area interface.

The steps to decontaminate and eventually release each of the buildings described in this section inclided :

- removal of process equipment and utilities to permit glovebox removal;

- removal of gloveboxes and conveyor tunnels;

- removal of remaining process equipment, including air exhaust systems and drain Iine systems:

- removal of contaminated nonload-bearing wall partitions:

- decontamination of remaining floors, walls. ceilings, and utillty service systems:

- final radiation/contamination surveys;

- spot decontamination and resurvey if contamination was located;

- painting of walls and ceilings and installing of lincleum on floors: and

- release to new occupants.

New occupants received an Indoctrination and a final condition report for their assigned area. The report contained site drawings and post decontamination pictures plus special health physics control procedures for the area and site.

A. Building 150

Butlding 150 (Figs, 9 and 10) was built in 1963 as a plutonium fuels development building with glovebox lines perpendicular to a north-south overhead conveyor tunnel system. Some of the programs the building supported includad development of

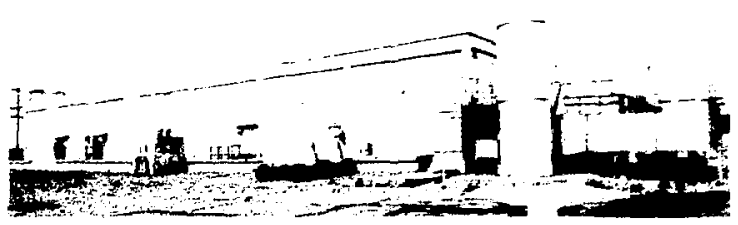

Fig. 9. Northeast side of Building 150.

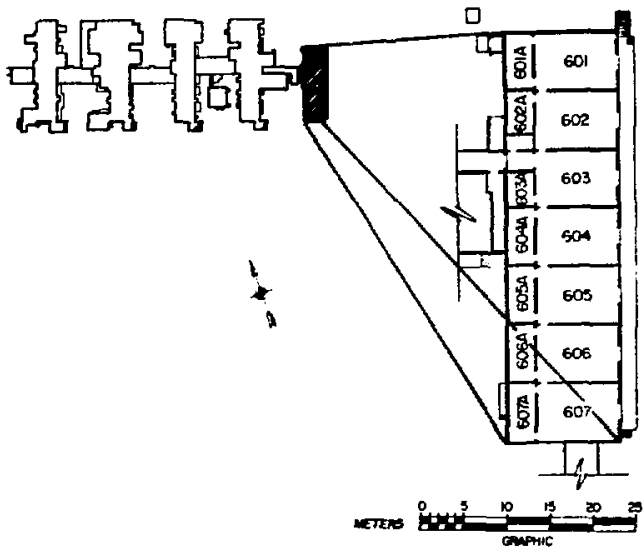

Fig. 10. Floor plan of Building 150.

${ }^{238} \mathrm{Pu}$ heat sources for space electric power applications, inves $\cdots$ un of the suitability of various plutoniun-containing ceramic materials as potential fuels for application in the Liquid Metal Fast Breeder Reactor (LMFBR) Program, and development of isotopic powered heat sources using ${ }^{238} \mathrm{Pu}$ as the fuel for powering artificial organs.

Few contamination incidents had occurred in this building; however, releases had occurred in Rooms 603 through 607 . The areas had been cleaned to a low swipe count and painted to contain the contamination. Three trouble areas where plutonium contamination was know included (a) the roof over Room $605 \mathrm{~A}$, which had become contaninated during a release from a hood vent in 1970; (b) the outside dock east of Room 607 contaninated in 1970; and (c) some basement areas around vacuum punps which had a history of oil lezkage under the pup bases.

Removal of process equipment such as chilled circulating water system piping, industrial liquid waste lines, vacuum lines, and air exhaust systems presented few difficulties because most of the pro- 
cess piping was exposed in the building basement (Fig. 11).

Because of the ample work space and the ability to remove wall sections under the material conveyor tunnel (Fig. 12), gloveboxes and conveyor tunnels were easily separated for removal. Approximately $84 \mathrm{~m}$ of gloveboxes and $44 \mathrm{~m}$ of conveyor tunnels were removed. The conveyor was separated into seven sections for packaging and storing as retrievable waste.

The remaining process utility lines and the process a1r exhaust were also removed (Fig. 13). Water lines, compressed air lines, etc., were removed to the basement and capped. The room air exhaust system was cleaned to the filter plenum located outside and northeast of the building. The fresh air supply system had low-level contamination on some internal surfaces so the complete system was removed and later replaced. The entire roof surface was removed and replaced with a new tar and gravel roof. The circulating chilled-water system was dralned and flushed until no activity could be detected in the water. It was left in place at the request of the incoming occupants. The asphalt and soil near the outside dock east of Room 607 were removed (Fig. 14).

After removal of all detectable contamination by a decontamination crew and damp wiping or mopping of all interior surfaces by a janitorial crew. all surfaces were monitored by health physics personnel. The walls were painted, new sheet $l$ inoleum

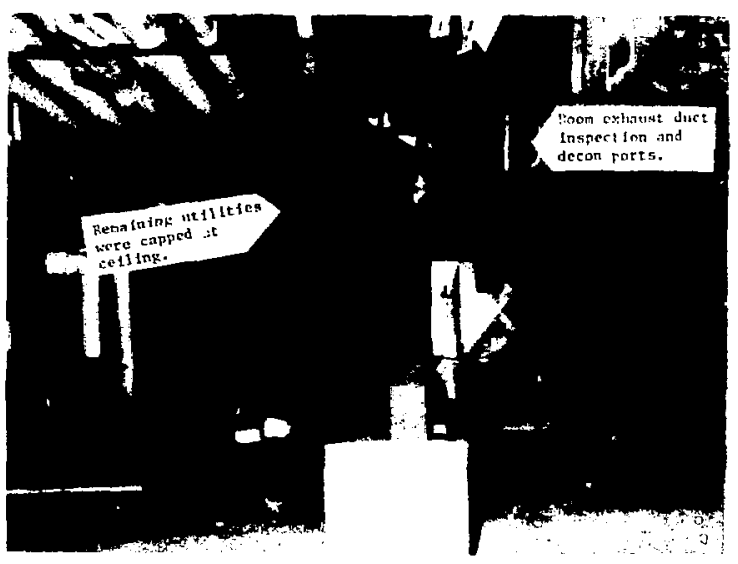

Fig. 11. Bullding 150 basement, overhead utilities.

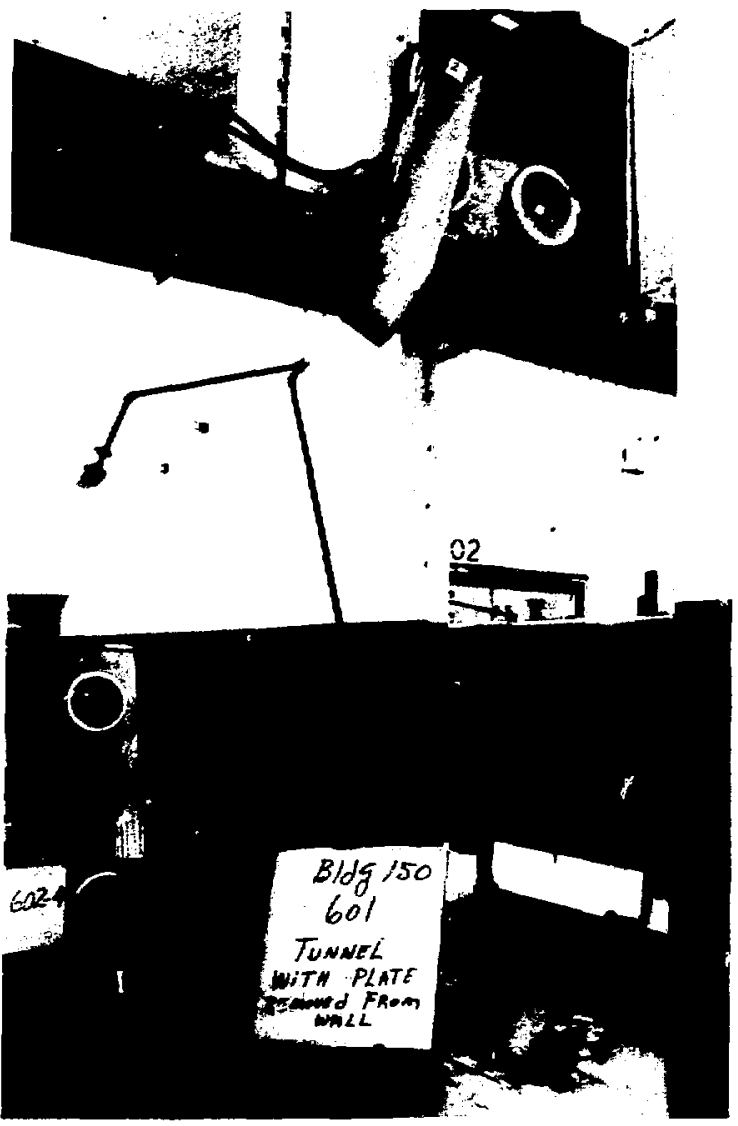

Fig. 12. Bulding 150, removable wall under conveyor tunnel.

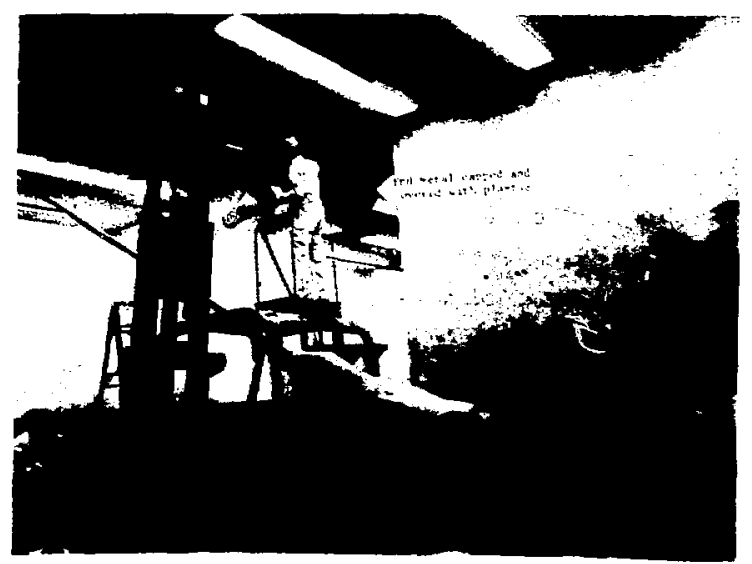

Fig. 13. Removal of process air exhaust, Dullding 150. 


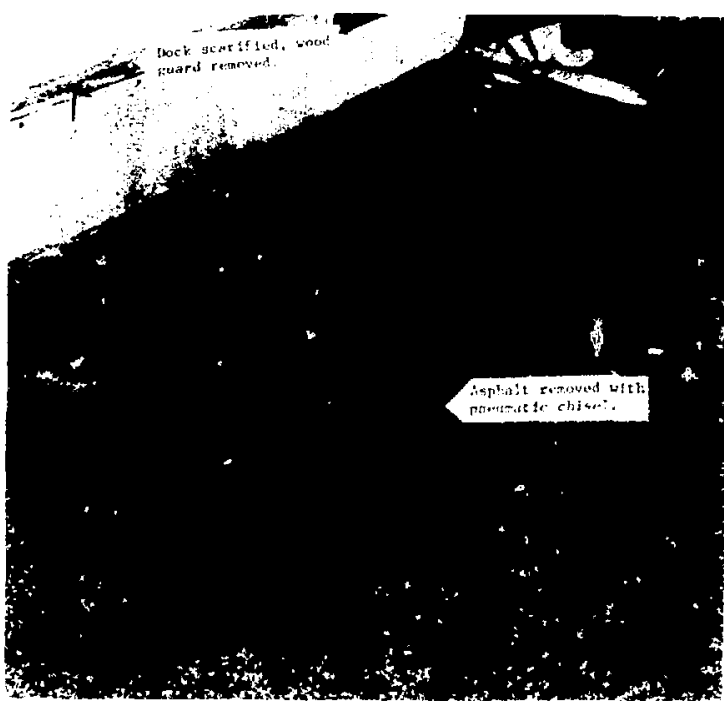

Fig. 14. Removal of asphalt and decontamination of loading dock, Building 150.

floor covering was installed, and photographs were taken for final documentation (Fig. 15). The building was released to the Inorganiz and Structural Chemistry Group ( $\mathrm{CNC}-4$ ) of the Labordtory's Chemistry-Nuclear Chemistry Division.

B. Building 5

Puilding 5 (Figs. 16 and 17) was the piutonium metal fabrication facility. In 1963, Room 506 was constructed to house electrorerining equipment needed to produce high-purity plutonium metal. Also in 1963, room 500A was added to house an air drying system for air supply to the conveyor tunnels and gloveboxes.

Work conducted in Building 5 centered around the production of plutonium metal and metal alloys and the fabrication of precision plutonium parts for nuclear devices in support of the Laborator $y^{-1}$ National Security programs. In 1964, Rooms 530-534 were added to provide additional fabrication and testing facilities. ".. is addition had a basement for electrical panels, waste lines, and other service systems,

Until 1974 all work was with ${ }^{239} \mathrm{Pu}$ for the weapons program. In $1975,{ }^{238} \mathrm{Pu}$ was introduced into one glovebox chain in Room 500 for limited research work on testing of high-efficiency particulate air (HEPA) filters.

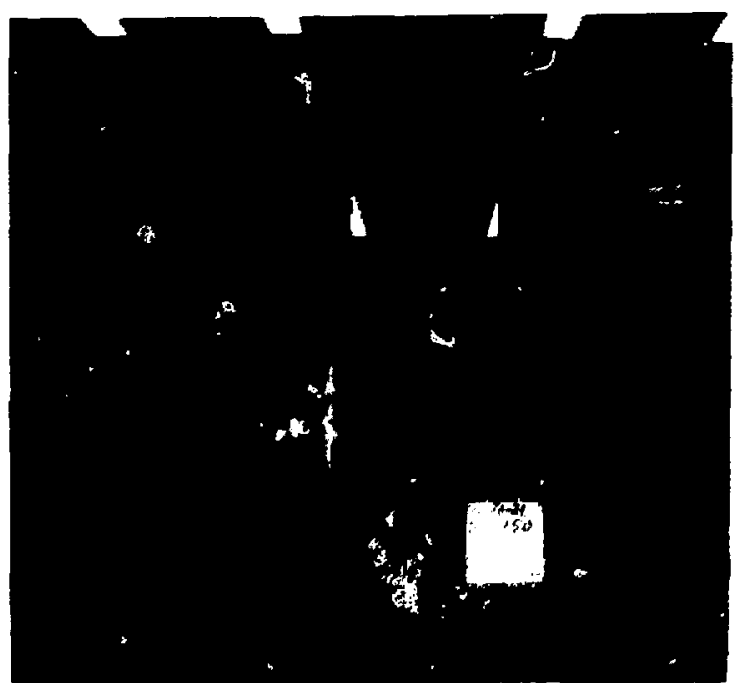

Fig. 15. Typical room after decontamination.

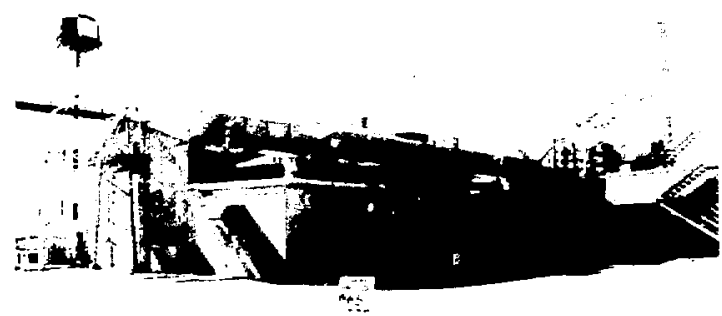

Fig. 16. Northwest side of Building 5 .

In Building 5 decontamination operations became more complicated. Instead of process piping being accessible in a basement, piping dropped from the gloveboxes into $0.5-m$ deep, $0.6-m$ wide trenches (Fig. 18) then traversed each room to $1.2-m \times 1.2 \rightarrow$ utility tunnels which extended around the entire perimeter of the building (Fig. 19). Piping in the congested tunnels included water, steam supply and return, industrial waste sewer, caustic supply and return, helium, argon, air, two chilled water supplies, and return systems and hot water. The entire electrorefining glovebo. lines in from 506 had been relocated to the new plutonlim facility before starting the decontamination of the rest of Building 5.

The first step was to free the gloveboxes for removal. Tinners, fitters, and electriciens re- 


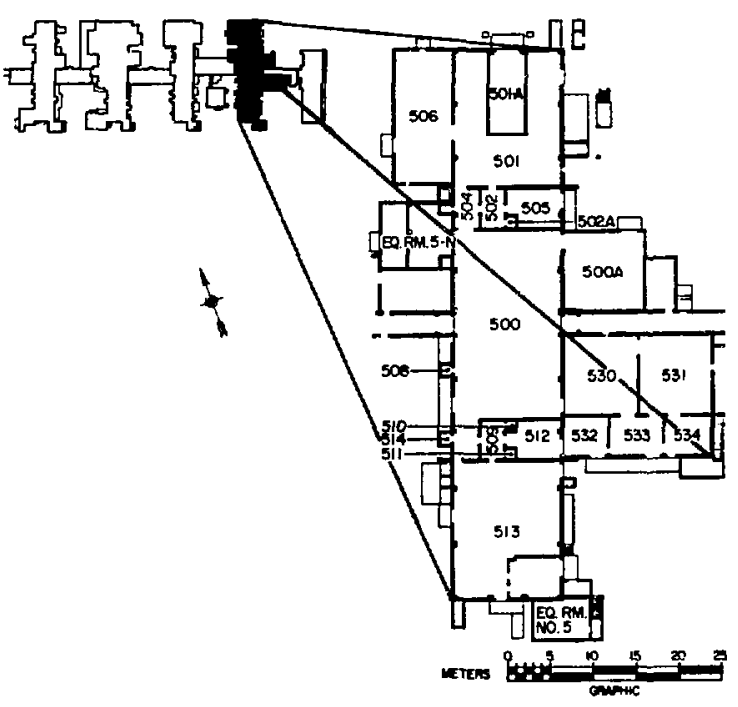

Fig. 17. Floor plan of Suilding 5 .

moved all utilities down to the point of entry to the trenches except for one connection to the process air exhaust system. Part of the exhaust ductwork was replaced with an extra-long nexible wiremold hose to permit movement of the box while maintaining a vacuum during separation (Fig. 20). In some cases utility lines were embedded in the concrete floor (Fig. 21).

The gloveboxes were also more difficult to remove than those in Bullding 150. They were larger, had more external equipment connected to them, had larger openings at the separation points, and (particularily in Room 500) had less space between boxes (Fig. 22).

The material conveyor tunnels presented new problems in that there were interconnecting tunrel systems (Fig. 23) and there were fewer gloveports for cleaning and inspecting. In one case, a section $18 \mathrm{~m}$ in length was disconnected and lowered for further separation into shorter lengths at floor level.

Removal of equipment, Bloveboxes, and conveyor tunnels was followed by removal of surface contamination. The task was complicated by many cozts of paint applied to contaminated walls and floors during the 33 years of use. Alpha survey instrumentation would not jetect plutonium through the paint, yet the background was too high for gamma radiation surveys to be meaningful. It was only

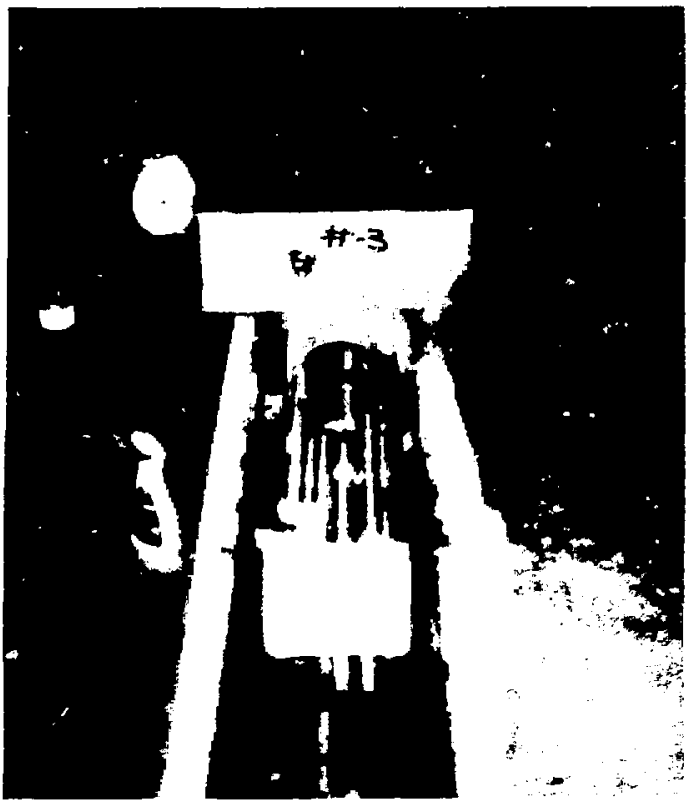

Fig. 18. Typlcal floor trench in Bullding 5 before removal of utilities.

after removal of the concrete floor surface and removal of plaster from the more highly contaminated walls (Fig. 24) that the gamma survey instruments could be employed. After pipes in the room trenches were removed, the trenches iere decontaminated to a no-swipe level and filled with concrete.

The perimeter utility tunnels were decontaminated by removing highly consaminated lires, i.e.. vacuum, liquid waste, and circulating water lines. All other innes were isolated, sealed, and abandoned in place because the cunnels could not have been tntally decontaminated without destroying the integrity of the building. Cramped working quarters with limited egress were thought too hazardous to warrant additional decontamination effort. All entrances to the tunnels were eliminated by filling the openings with concrate except at the north and south ends of the building. These entrances for Buildings 2 and 5 tumnels were covered with locked metal covers (Fig. 25).

The attics were in much better condition than would be normally expected at a 33-year-old facility because they were cleered during the 1974 ventilation and fire protection upgrading project. All accessible services were danp-wiped, Monitored, and spray painted with an asphalt enulsion. 


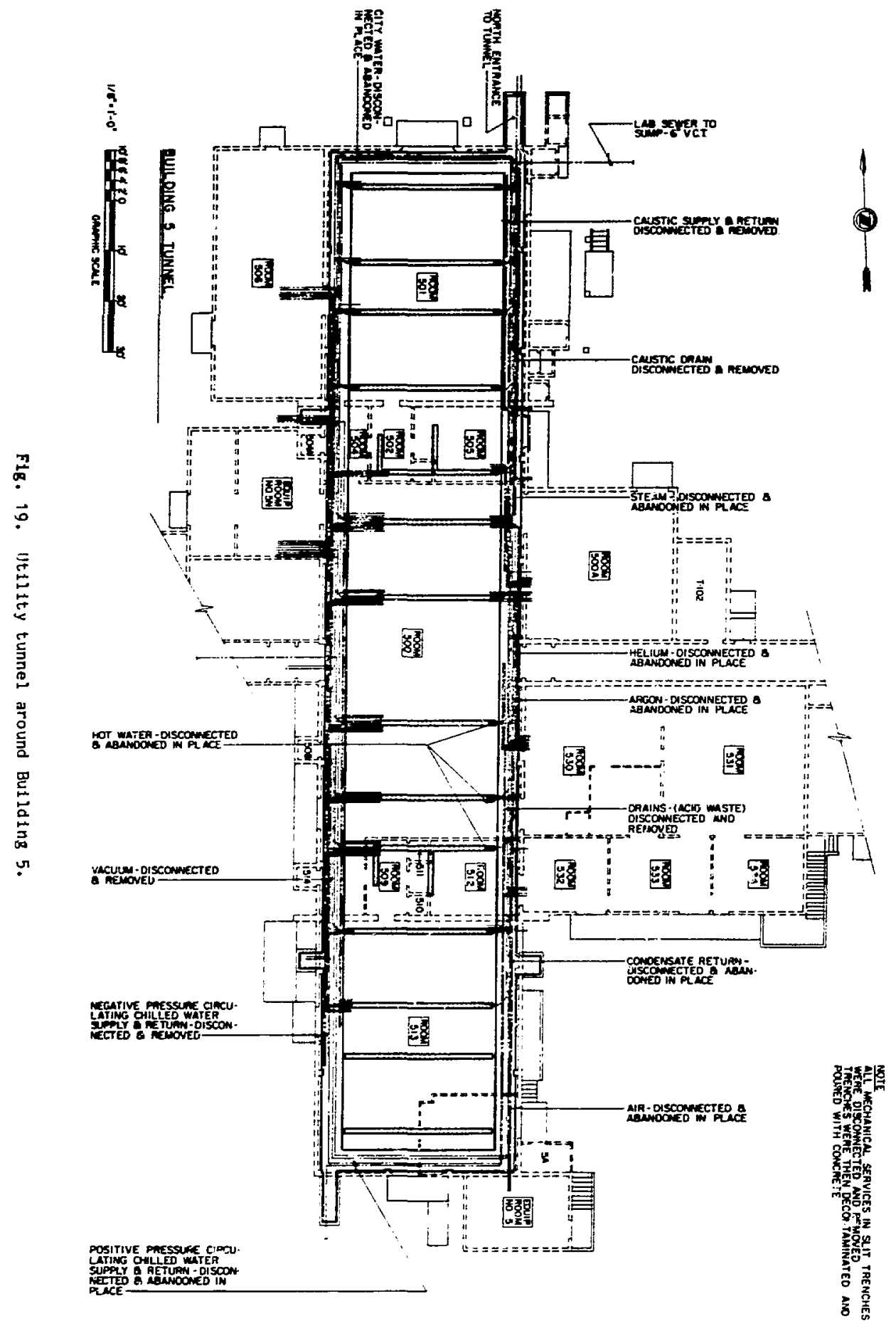




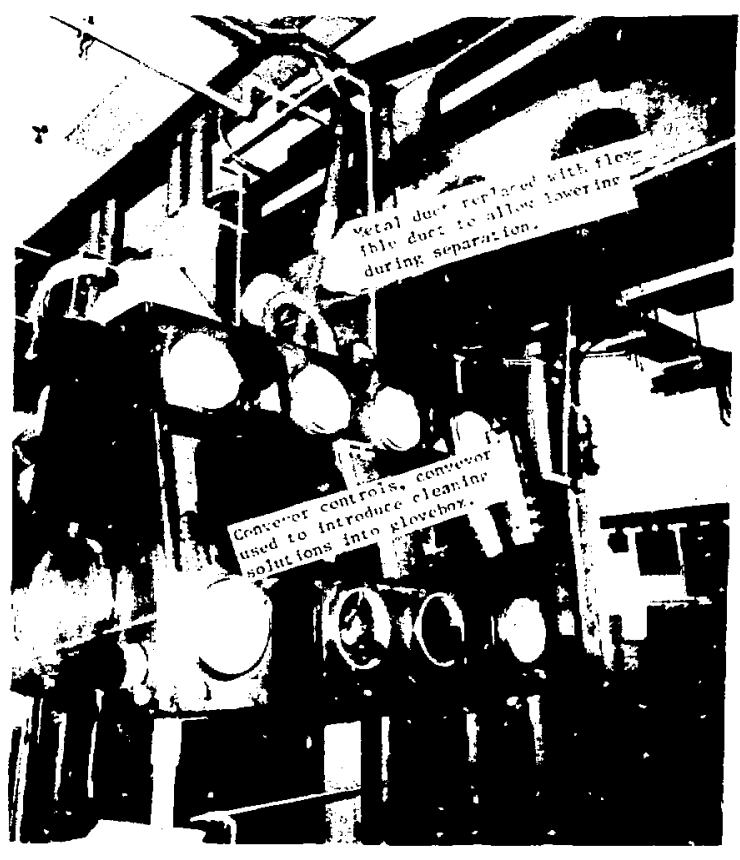

Fig. 20. Glovebox ready for separation.

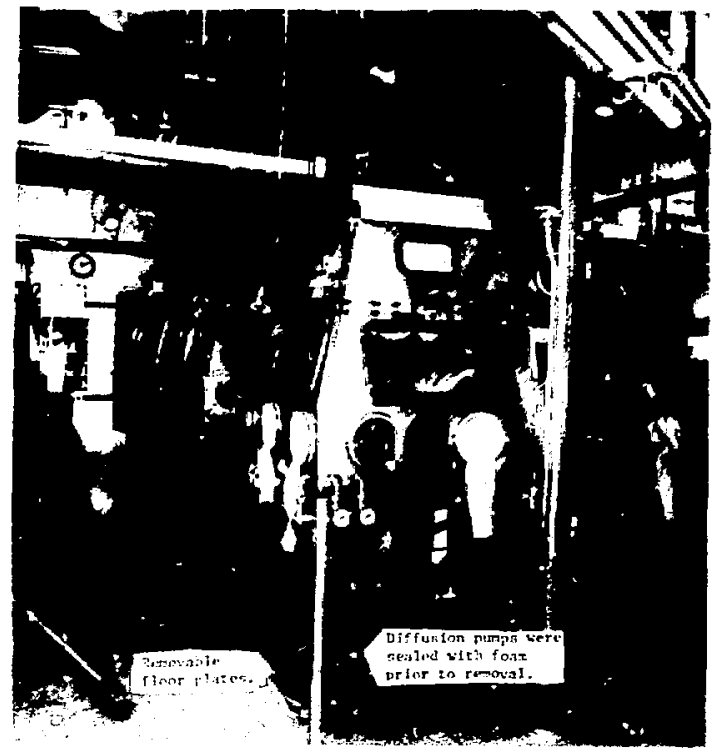

Fig. 22. Typical gloyebox line in Building 5 .

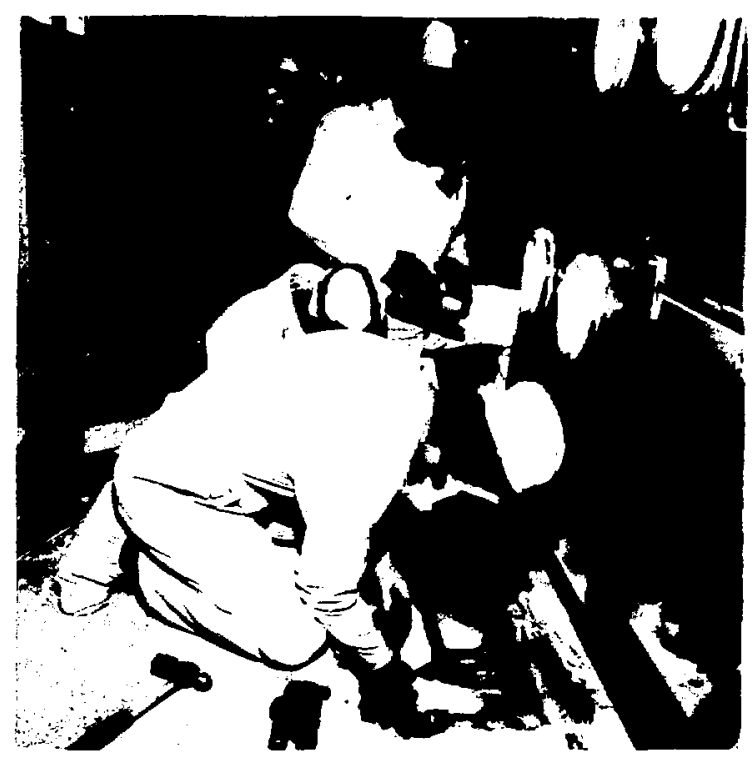

Fig. 21. Utility lines embedded in concrete. Building 5 .

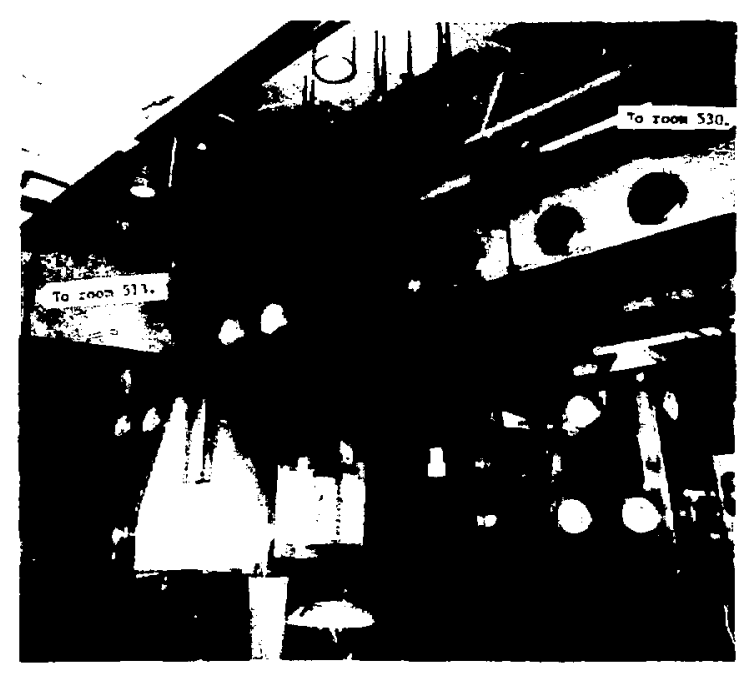

5ig. 23. Glovebox tunnel connection in Bullding 5. 


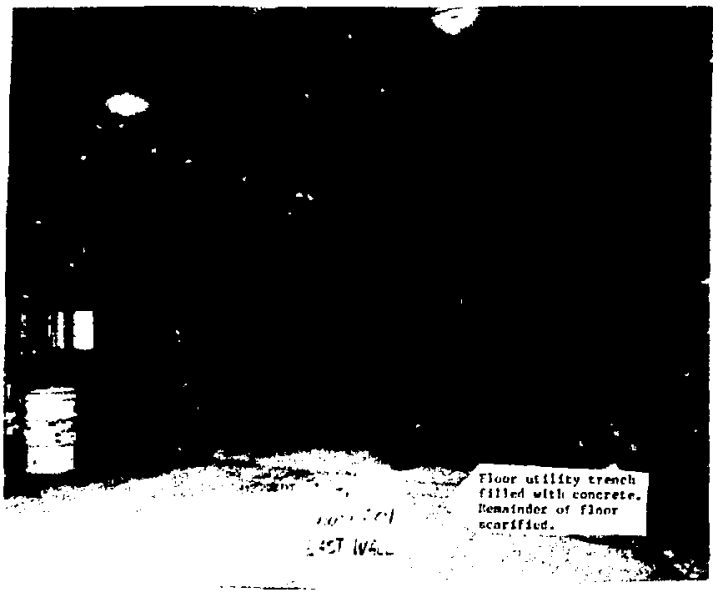

Fig. 24. Bullding 5 wall after decontamination.

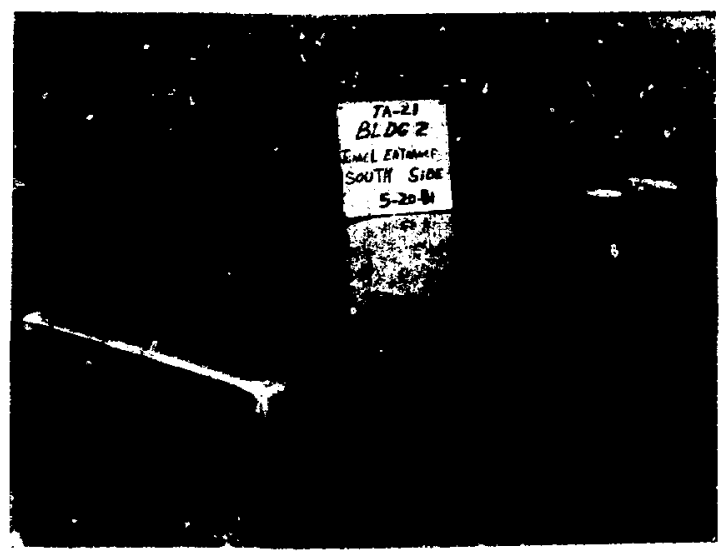

Fig. 25. Metal covering over utility tunel entrance.

After decontamination, which included the removal of some $85 \mathrm{~m}^{2}$ of plaster from walls and cellings and $240 \mathrm{~m}^{2}$ of concrete floor surface, the walls and ceilings were replastered and painted. The floors were leveled and covered with sheet linoleum. In Room 501 a new 8- to 10-cm concrete floor was poured before laying the linoleum.

The bullding was assigned to two Laburatory groups. The north half, including all of Room 500 , is used by the Electronics Division for fuel cell studies. The south half is assigned to the Laboratory's Plutoniun Chemistry and Metallurgy Group as a photographic processing facility.

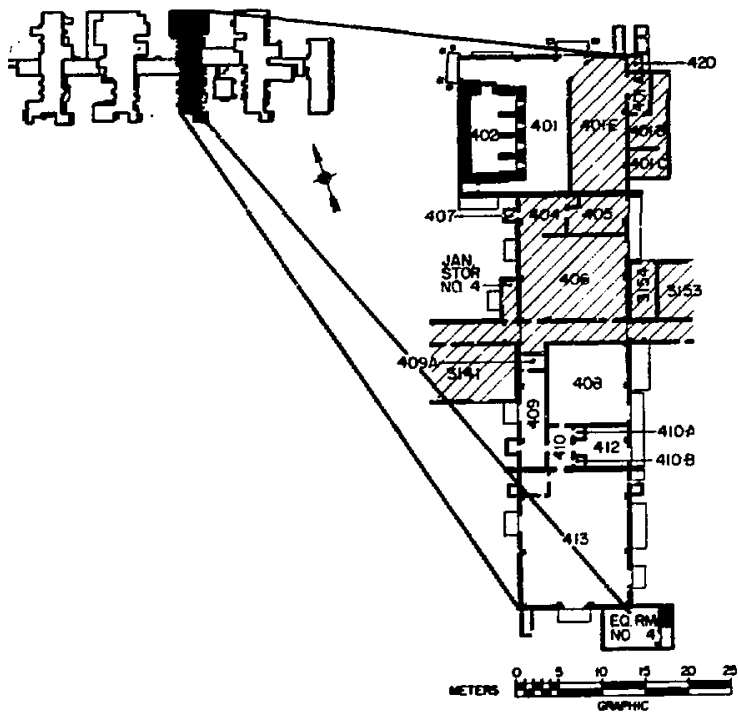

Fiz. 26. Building 4, iocation of decontaminated areas.

\section{c. Biliding 4}

Only part of Building 4 (Fig. 26) was decontaminated since ongoing operations continued in Rooms 401 and 402 occupied by the Irradiated Materials, Examination and Handling Group (CMB-14) and in the south half of the building by the Physical Chemistry and Metallurgy Group (CMB-B). Both groups were able to continue normal operations during the decontamination of the $401 \mathrm{E}$ and 406 room areas with minimal downtime.

1. Rocm 401-E and Support Roons 401-A, 401-B, and $401-C$

From 1945 until 1948, Room 401, which was later divided into $401-E$ and 401 , was a development laboratory for plitonium research. It was decontaninated in 1948 and was converted to an enriched uranium hydride production area. In 1960 all hydride equipment was renoved, the area was again decontaminated, and a hot cell for the exanination of irradiated plutonium and enriched uranium fuel elements was constructed on the west side of the roon.

In 1965 a partition in floom 401 created room 401-E in which two glovebox lines were installed to support ${ }^{238} \mathrm{Pu}$ metal production work. This area uns decontaninated early in the decontmination project along with the three support areas (Fig . 27). 


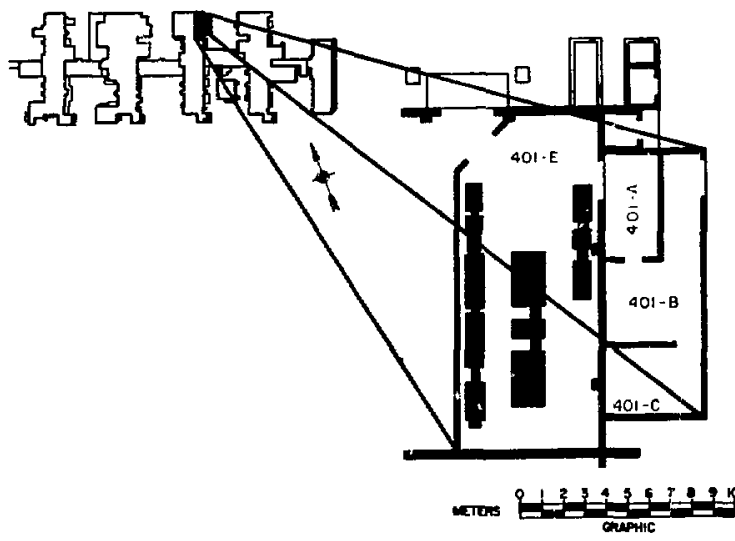

Fig. 27. Floor plan of room 401-E and adjoining support rooms.

The gloveboxes in $401 E$ were similar to those in Building 150 in that they were 1 inked by circular connecting ports which facilitated separation. The $16 \mathrm{~m}$ of gloveboxes (FIg. 28) were removed in approximately two weeks.

Because the process piping was less complicated than in other major areas such as Buildings 5 and 150 , this area was the first to undergo all the steps in the decontamination operation and was the first to be released.

Two previous decontaminations (1948, 1960) and the absence of serious plutonium-238 contamination resulted in the roons being easily decontaminated. Room trenches were filled with concrete after decontamination to a no-swipe level using procedures described for Building 5. The walls were repainted and new I inoleum was installed.

The utility tunnels for this building were not in the scope of this project since all utilities had to be preserved for operations in the other parts of the building. The tunnels, however, are not as contaminated as the Building 5 tunnels.

The process air exhaust system in Room 401-E was removed to the north wall and capped off to allow easy reuse by future occupants. Rooms $401 \mathrm{w}$, $401-A, 401-B$, and 401-C were transferred to the Laboratory's Inorganic and Structural Chemistry Group (CNC-4) for low-level chemistry work with transuranic elements.

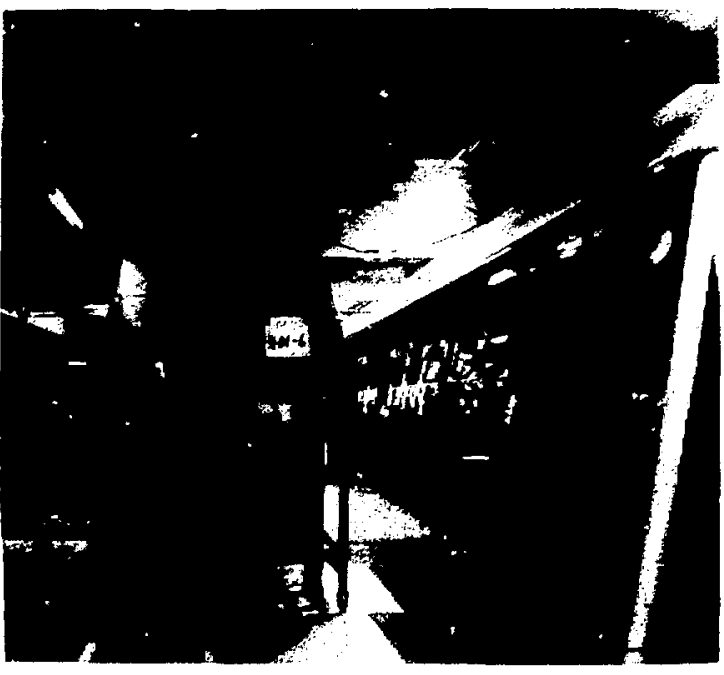

Fig. 28. Glovebox in roons 401-E.

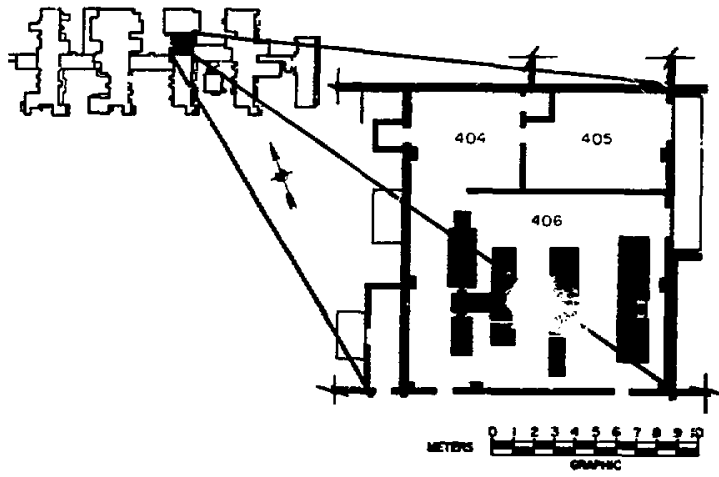

Fig. 29. Floor plan of room 406 and adjointing support rooms.

2. Room 406 and Support Roons 403, 404, 405. and 407

Contamination levels in this area (Fig. 29) were similar to those in Building 5 , since it had been used as ${ }^{239} \mathrm{Pu}$ and ${ }^{238} \mathrm{Pu}$ metal preparation area during the early years. Extensive decontmination was required since Room $406 \mathrm{slso}$ had a history of spills dating back as early as 1948. The floor had been painted to contain contanination at least 25 times between 1948 and 1970.

The 12.7 in of gloveboxes were removed, the process exhaust was renoved, and the roon trenches were filled with concrete. The wils were free of contamination: however, $12 \mathrm{~m}^{2}$ of floor surface area required removal. Services in the utility tunnels 
had to remain to support ongoing operations in the rest of the building. The walls were painted, new linoleum was installed, and the rooms were transferred to the Inorganic and structural Chemistry Group ( CNC-4).

\section{Building 3}

The decontamination operation in Building 3 was confined to Room 308 and adjoining support rooms (FIB. 30). The rest of the bullding was excluded because the north half of the building. occupled by the Inorganic and Structural Chemistry Group, had earlier been 1 solated from the main plant complex and because the enriched uranium scrap recovery operations continued in the remaining southside rooms.

During decontamination operations, exterior doors frm the work area were sealed and a fence erected to eliminate possible tracking of contamination and to control traffic.

The records search indicated that foom 308 was possibly the most highly contaminated room to be decontaminated. Plutoni um-238 and ${ }^{239} \mathrm{Pu}$ had been processed in the room in old gloveboxes (Fig. 31) and numerous contamination incidents had occurred. The decontamination approach was similar to that used in all the other buildings, except in floom 308 almost all work required respirators. The west wall and a portion of the celling plaster were highly contaminated and had to be removed. These walls and ceilings were replastered and painted.

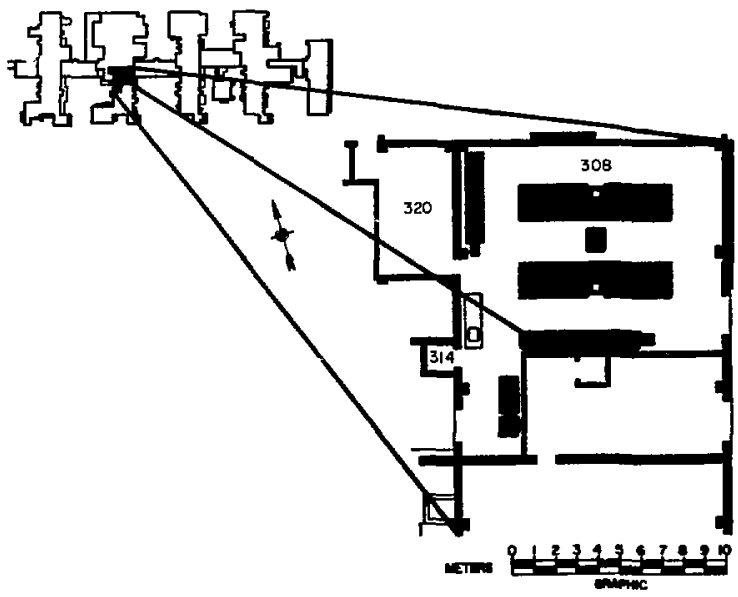

Fig. 30. Floor plan of Room 308 and adjoining suppori rooms.
The main overhead electrical service bus conduit to other south side rooms was decontaminated, sealed, painted, and left in place. The rooms were released to the Laboratory's Physical Chemistry and Metallurgy Group (CMB-8) as additional storage space and solution makeup area for their adjoining enriched uranium recovery operations.

\section{E. Building 2}

Building 2 (Fig. 32), had a history of spills and releases. In addition to numerous gloveboxes used for dissolution and recovery of plutonium and storage of 241 Am wastes, the building housed a scrap incinerator, solvent extraction columns, and a 11 quid-waste-loading area. Unlike the other buildings, Building 2 had $165 \mathrm{cyl}$ indrical stainless steel licuid storage tanks and several 3.8-m columns to contend with (Fig. 33). The dirficulties of handling and transferring plutonium solutions not only from glovebox to glovebox but also from room to room had resulted in many solution spills and extensive floor contamination.

A team of two pipefitters and one health physics technician (HPT) separated the storage tanks, columns, and lines. This operation was begun as early as possible in 1978 to avoid the maintenance that would be required if the tanks were unattended until the regular decontamination crews arrived in Bilding 2 .

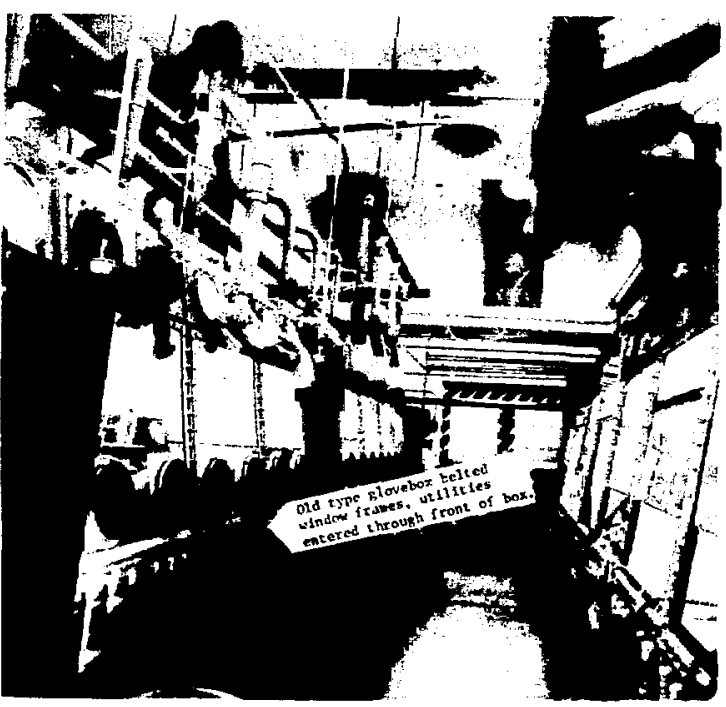

FiB. 31. Gloveboxes in roon 308. 


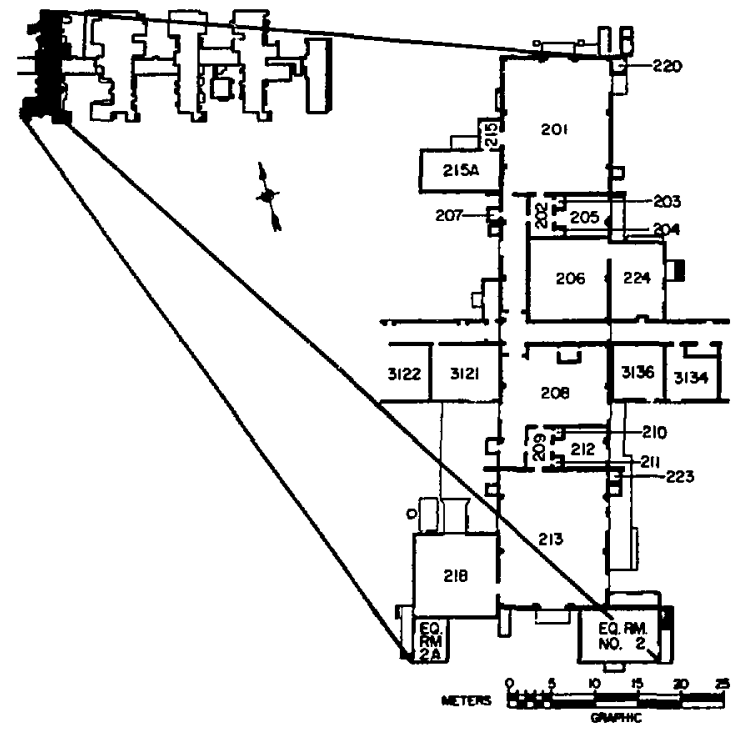

Fig. 32. Floor plan of Bullding 2.

Decontaminating this building presented problems not previously encountered. The floors were generaliy more contaminated than in other buildings. A plastic enclosure similar to the one used for a glovebox separation was constructed over the floor utility trenches in Room 201. It was used to control air rlow during the removal of process piping and during initial decontamination operations. A section of external wall on the northeast side of the building required surface removal. In Room 213, a large glovebox that had a wall in common with a room wall and two satellite gloveboxes required a simultaneous separation in two directions (Fig. 34). The section of utility tunnel between Rooms 213 and 218 was known to be highly contaninated. The tunnel was entered from above and approximately $0.5 \mathrm{~m}^{3}$ of soll containing approx inately $13 \mathrm{grams}$ of ${ }^{239} \mathrm{Pu}$ and ${ }^{241}$ Am were removed.

All other aspects of the decontamination and release operation were similar to those described for the other areas.

The building was assigned to th: Enviromental Studies Group (LS-6) of the Laboratory's Life sciences Division. It will be nodified to provide the group offices and chemistry labs.

\section{F. Bullding 286}

Building 286 , a $350-m^{2}$ metal warehouse building with metal fraing/drywall partitions (F1g. 35)

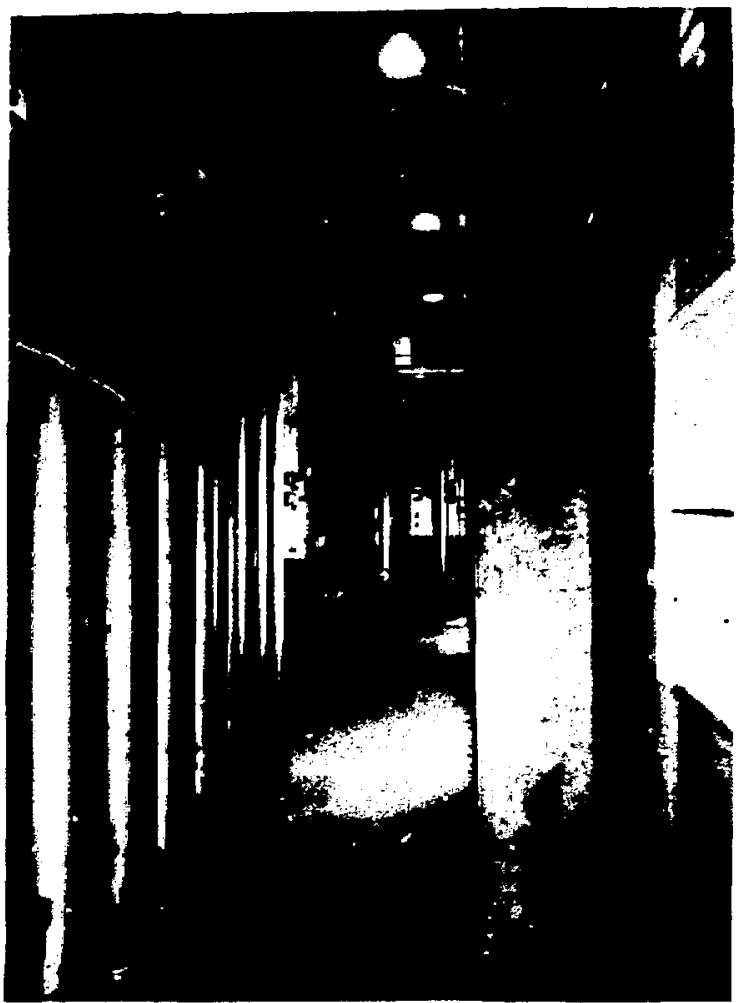

Fig - 33. Storage tanks and column in Building 2.

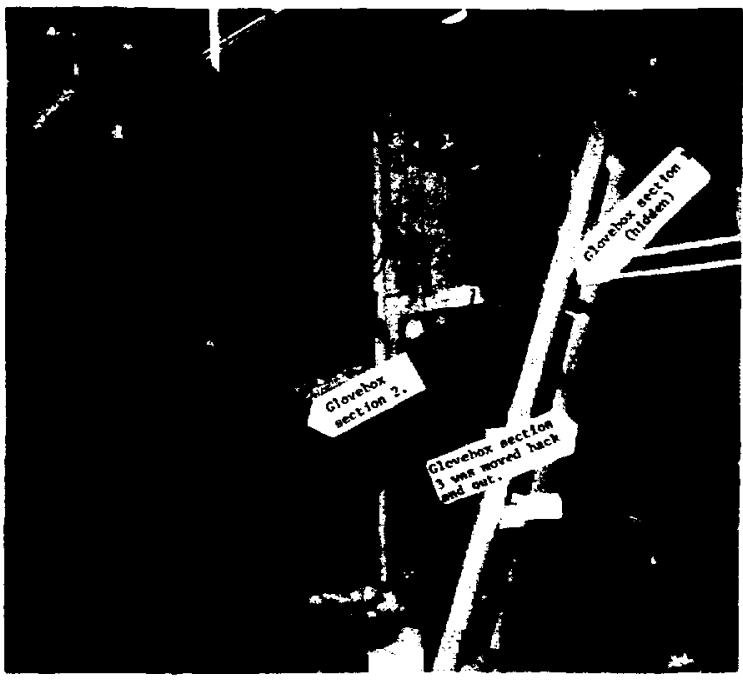

Fig. 34. Gloveboxes ready for separation in two directions. 


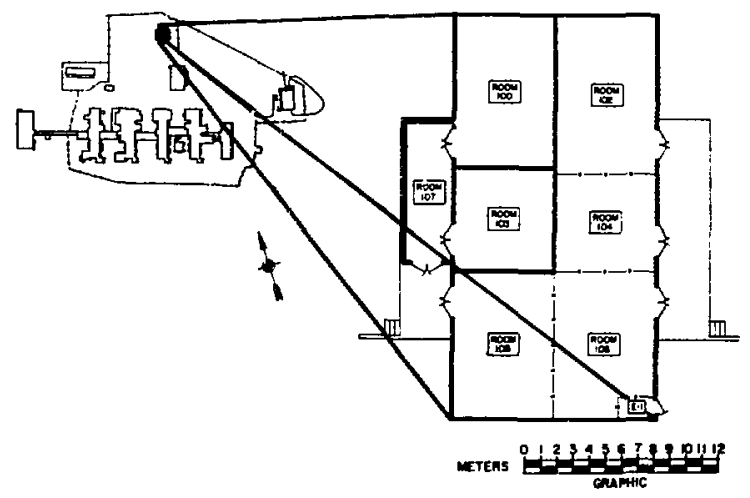

Fig. 35. Floor plan of Building 286.

was built in 1972. Rooms 100 and 103 were used as storage vaults for plutoniun solutions. The rest of the building was used for equipment and material storage.

The northeast corner of room 100 was know to be highly contaminated under the paint and between the drywall separating rooms 100 and 102 due to a plutonium nitrate solution leak. The rest of the vault area was suspect, but the other rooms were essentially contanination free.

The building was decontaminated and transrerred to $\mathrm{H}-1$ as a warehouse for decontamination equi pment.

\section{G. Outside Areas \\ The project also removed five industrial} 11quid-waste collection and sampling wells. The wells were at the northeast corners of the four original buildings and the northwest corner of Building 150 (Fig. 36). The original well structures for Bulldings 2, 3, 4, and 5 were $4.65 \mathrm{~m}$ deep and $1.5 \mathrm{~m}$ in diameter and constructed of brick. Stainless steel liners were added later. The reinforced concrete structure for Building 150 was $1.8 \mathrm{~m} \times 1.8 \mathrm{~m} \times 4.65 \mathrm{~m}$ deep. Prior to removal, the remaining liquids were pumped from the wells and dry cement placed in each well to absorb any free water. When the cement had set, approximately 1.5 m of urethane foam was sprayed on top of 1 t.

Four of the five wells were removed in one plece by exposing them as much as possible with a backhoe then pulling them out with a crane. All surfaces were then sprayed with asphalt and the structures were urapped in plastic and turpaul ins and transported to $\mathrm{TA}-54$.

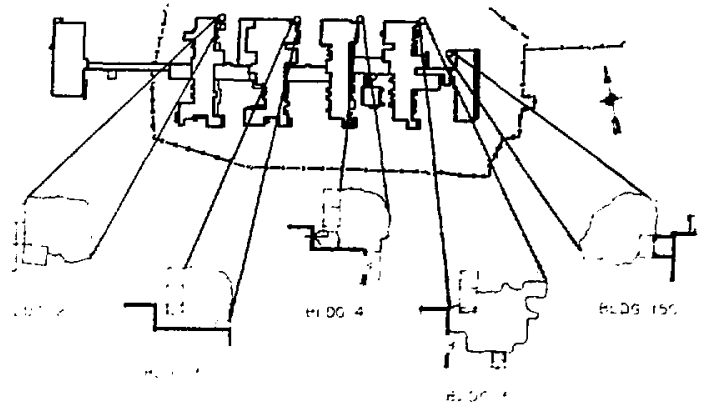

Fig. 36. Location of acid waste sampling wells.

The well from Building 2 collapsed during removal. The rubble was loaded into plastic-lined, tarpaulin-covered dump trucks and transported to TA-54. After removal of the acid wells, contaninated soil was removed to the point where further excavation would jeopardize the adjoining buildings or could best be removed at a later date when the waste lines are decommissioned. The remaining contamination was documented as to anounts and locations and the pits were backfilled with clean soil. The contaninated pit walls were sprayed with asphalt to alert personnel excavating in the area in the future.

Although the acid well renoval was the only pl anned external work, the records search indicated considerable contamination existed southeast of Bullding 2 under the asphalt covering and in an abandoned acid line between Bufldings 2 and 3 . Eighty cubic meters of soll and 13.2 m of pipe were removed and the area was resurfaced with asphalt to match remaining paved areas.

The asphalt driveways around the buildings were surveyed. Soll from several small areas ranging from 0.1 to $0.3 \mathrm{~m}^{2}$ in size was found to be above acceptable limits and ws removed.

\section{v. HEALTH PHYSICS}

Group H-1 was responsible for worker protection and for providing tralned technicians for radiation monitoring of jobs and decontaminated areas. A health physics section ws maintalned at the facility throughout the operation. Th: section was supervised by a starf health physicist. Neporting to the health physicist ws supervisor 
who functioned as the first-line supervisor of the technician crew which ranged in size from two to six when the operation peaked in 1979 and 1980.

The decontanination section technicians performed extensive surveys while performing their jobs to determine the effectiveness of their efforts. Their knowledge of radiation protection and monitoring allowed them to proceed with minimal health physics support. However, the health physics section was responsible for providing health physics support for decontamination personnel and their operations as well as for the construction contractor's activities. Health physics peryonnel also performed the final release surveys, documented the results of these surveys, and provided new occupants with information concerning restrictions and conditions pertaining to their assigned area.

This section describes the health physics program el ements and reports results of these program elements where appropriate.

\section{A. Personnel Protection}

Before being assigned to the project, workers were required to submit a plutoni un bloassay (urine) sample, have an in-vivo measurement for plutoni um, and be quantitatively fitted for fullface respirators. Workers thereaster submitted quarterly bioassay samples and particlpated in an anriual in-vivo measurement. Special in-vivo measurements were performed following a few suspected exposures (see below).

On assigrment to the project. workers attended a health physics indoctrination lecture. Among the topics addressed were (a) clothing requirements, (b) dosimetry badges, (c) respiratory protection, (d) eating and snoking regulations, (e) contamination control and use of self-monitoring instruments at exits from radiation areas, (f) nasal smears, $(g)$ wound counting, and $(h)$ site and work area alarms.

Each work crew was assigned an HPT whose primary responsibility was to keep personnel radiation exposures as low as practicable. To implement this responsibility, the Radiation Hork Pernit (RWP) was initiated by operations personnel, submitted to the health physics supervisor for identification of radiation protection requirements, and copy given to the HPT. No job was performed without the RMP and no change in operation or in protective requirements was allowed without approval by the operations and health physics supervisor.

The permit was initiated following a near-ialss exposure incident in October 1979. Since this incident resulted from a field decision to use a power saw Instead of a hand saw to remove a section of contaminated sheet rock dry wall, the investigating committee recommended tighter controls on operations and field changes.

The RWP caused some delays while personnel became accustomed to ensuring that the permit was avallable when needed. It soon proved very vallable in assuring that personnel were protected and that changes were reviewed. Decontamination activities were monitored by HPTs either continuously or intermittently, commensurate with the requirements identified in the RWP. All workers were required to ar theimoluminescent dosimetry (TLD) badges. Figure 37 shows monitoring activities during decontamination operations.

Special personnel monitoring procedures included wound counting ${ }^{4}$ and urine and fecal sampling. 5 The criteria for these procedures follow along with results concerning frequency and findings.

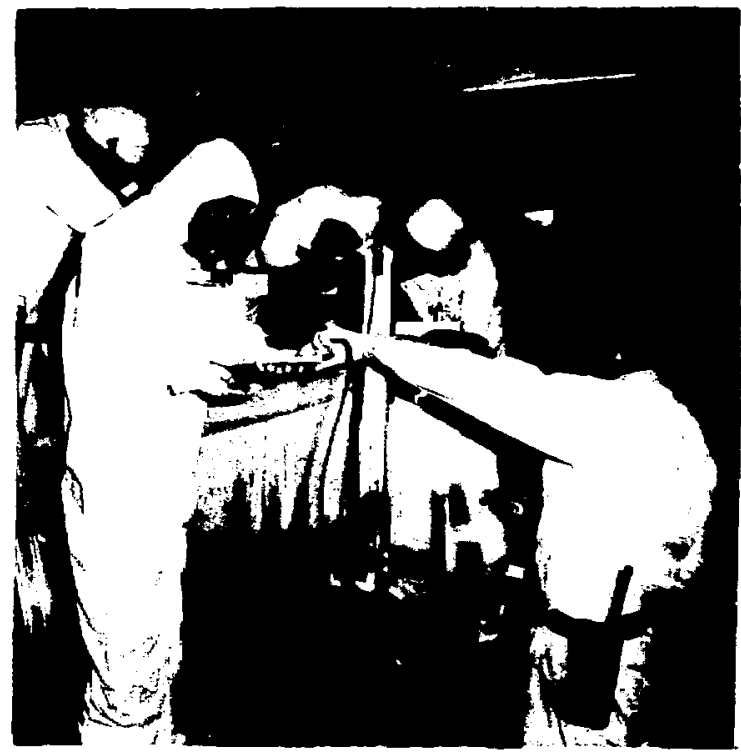

Fig. 37. Health physics monitoring during glowebox separation. 
A part of the training for the HPT assigned to a work crew was documenting and responding to wounds because the nature of the work resulted in numerous minor skin scratches, abrasions, or punctures. Although the Laboratory's plutonim wound count procedures address many wound and infury situations, the basic rules for the minor wound were that a wound count would be required if the wound occurred in a plutonium work area and (a) if alpha contamination was found in the vicinity of the wound; (b) if alpha contamination was found on the object causing the wound; or (c) if the object causing the wound could not be monitored but was suspected for any reason of being contaminated; or (d) if the worker or his supervisor specifically requested a plutonium wound count.

Seventy-five such wounds were reported and counted during the operation. None contained a measurable amount of plutonium.

A program for collecting fecal samples following potential exposures was initiated at Los $\mathrm{Al}$ amos in 1973. The program requires collection of fecal samples if any of these situations occur: (a) introduction of plutonium into tissue, to the extent that levels exceed $2 \mathrm{nCl}$ by the plutonium wound monitor: (b) chemical burns (acidic or alkaline) froin plutonium-bearing solutions which result, after attempts to decontaminate, in skin contanination in excess of $10,000 \mathrm{dis} / \mathrm{min}$ with a $60-\mathrm{cm}^{2}$ alpha air proportional probe, or in a plutonium wound count of the burn area in excess of $2 \mathrm{nCl}$; (c) facial contamination before decontamination in excess of $40,000 \mathrm{dis} / \mathrm{min}$ on an alpha probe near the nose or mouth or on the face as the result of a leaky respirator; or (d) nose swlpes (either side) in excess of $500 \mathrm{dis} / \mathrm{min}$ before blowing nose or showering.

On six occasions, personnel were requested to subnit fecal samples because of a nose swlpe in excess of $500 \mathrm{dis} / \mathrm{min}$. Levels in these sanples were less than the minimun detection level for plutonium and anericium.

B. Transfer Procedures and Finel Release Surveys In January 1979, a Standard Operating Procedure (SOP) was developed for final survey of the areas and eventual transfer of the areas to new occupants. The SOP was required to ensure proper surveys were performed and documented and to ensure proper indoctrination of new occupants. This procedure began with the termination of operations by the plutonium chemistry and metallurgy group and ended when the area was transferred to the new occupant. Th1s sequence was later incorporated in the project management plan.

The procedure called for personnel from the operations group to remain and ensure that the gloveboxes were given an initial cleaning to remove all accountable levels of plutonium and to guide the crafts through the removal of special equi pment and utilities from the gloveboxes. which became known as the predecontamination phase.

The room or area was then transferred to the Supervisor of the Decommissioning Section. Decontaminators from this section separated gloveboxes and conveyor tunnels and removed high levels of contamination. Skilled craftsmen removed contaninated services and miscellaneous equipment, and janitors and laborers removed lesser contaminated structures and surfaces.

The health physics section of $H-1$, which to this point had been providing health physics personnel to the craft and decontaminator crews, then took over the area to ensure that the decontamination effort met release criteria and that, any remaining contamination was documented. Final survey reports were prepared for each room and building.

When contamination levels in an area met predetermined release criteria, new flooring was installed, the walls were painted orange to alert future occupants of possible contanination, and a final condition report was prepared for each roan and building. A meeting was then held with the new occupants to discuss future use restrictions and health physics control program requirements.

\section{c. Rdiation Detection Instruments Used For Final} Sirveys

1. Alphe Survey Instruents

Since weapons-grade plutoniu, ${ }^{238} \mathrm{Pu}$, and 241 in were the prinary containants, and since the main project objective was to ensure surface alpha contmination 1 evels were below $1000 \mathrm{dis} /$ ain direct reading and $400 \mathrm{dis} / \mathrm{min}$ swipeable, alpha detection instruments played a major role in raciztion surveys, particularly in the final release survess. The two portable instruments used rere the borline Portable Alpha Counter Model 7 (PAC-7) and the 
Ludlum Model 139. The type used depended primarily on avallability; however, each had desirable features for certain situations. The approximate mininum detection level that could be detected using either instrument in the fleld was $400 \mathrm{dis} / \mathrm{min}$.

The PAC-7 is a small, lightwelght, batteryoperated count-rate meter with an integrally connected air proportional detector (Fig. 38). The clip-on meter module contalned the meter and speaker and was connected to the main case of the instrument by a coll cord.

The detector was an Eberline Model AC-2 4C attached directly to the electronics package with a Type $C$ connector. Efflclency for al pha was approximateiy 50s; active dacector area was $60 \mathrm{~cm}^{2}$. The Instrument's major drawack was the 12.7-cm helght and fixed detector which prevented using the instrument in congested areas such as piping chases and under gloveboxes.

The Ludlum Hodel 139 is a portable, batteryoperated alpha survey instrument with a cable connected detector. The detector was an air proportional detector with an $0.8 \mathrm{mg} / \mathrm{cm}^{2}$ aluminized mylar window. The active area was $50 \mathrm{~cm}^{2}$ and the instrument had approximately 508 efficiency.

\section{Beta and Gena Survey Instruments}

Beta-ganma surveys were made to verify that surface radiation levels were less than $1.0 \mathrm{mR} / \mathrm{h}$. Levels were found to be below the detection capabilities of this counter. Since the laboratory areas were to be released for occupancy by nonradiation workers, long-term thermoluminescent

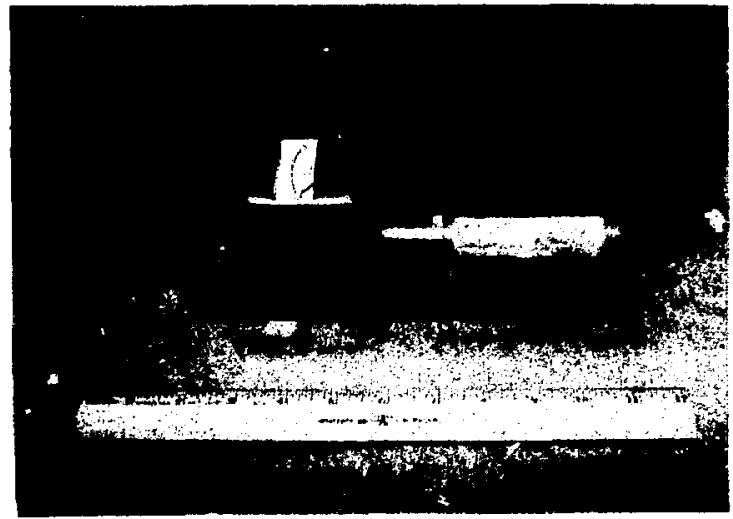

Fig. 38. Eberline Portable Al pha Detector Model 7. dosimetry badge exposures were ande to denonstrate that beta-gamma levels were below $0.25 \mathrm{arem} / \mathrm{h}$ or $500 \mathrm{mrem} /$ year based on a 40-hour-per-week. 50-weeks per - year occupancy factor. Thermoluminescent dosimetry badge results showed beta-gana radiation levels were not significantly different than natural background levels for the area.

The instrument used most frequently for betagand surveys of building surfaces was the Eberline E-112B meter (Fig. 39) and a 3-cm dian, by 16-clong halogen-filled GM twe wh $30 \mathrm{mg} / \mathrm{cm}^{3}$ stainless steel wall. It detects photon radiation from $20 \mathrm{keV}$ to several keV and beta radiation $>200 \mathrm{keV}$. The detection range was $0-20 \mathrm{mR} / \mathrm{h}$ with a typical background reading of $0.1 \mathrm{mR} / \mathrm{h}$.

A Ludlum Hodel 14 was occasionally used instead of the E-112B. It used the same probe end had basically the same detection capabilities as the sberline E-112B. All beta-ganna radiation final surveys of areas were performed with the detector shield open.

3. Heutron Survey Instrugent

Neutron surveyz were performed to measure neutron radiation levels throughout the facility. These surveys were performed using an Eberline Portable Neutron REM Counter, Model PNR-4. In addition to making surveys with this counter, the detector, which is a $22.9-\mathrm{cm}$ (9-in)-diseter. cadmium-loaded polyethylene sphere with a $\mathrm{BF}_{3}$ detector in the center, was used with a scaler system to make fixed location measurements

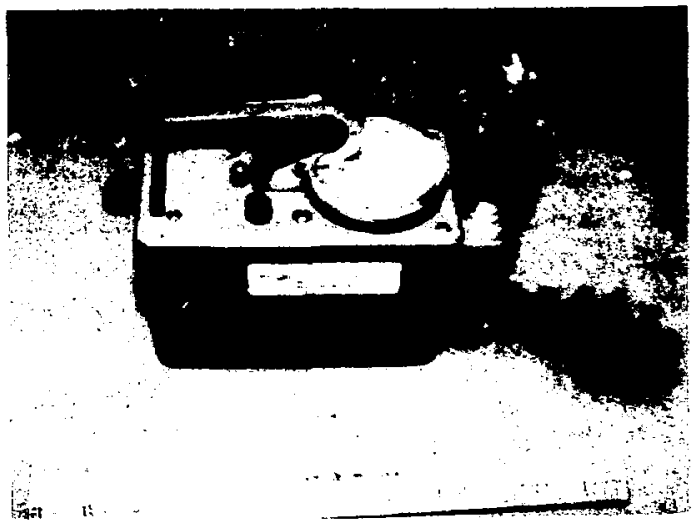

Fig. 39. Portabie beta-gene Doerline Meter Model E-1128. 


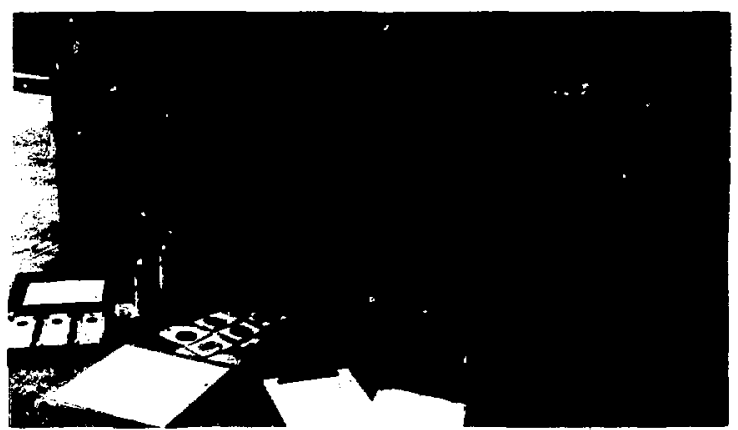

Fig. 40. Battery-operated portable phoswich detector.

throughout the facility. Th1s system was capable of measuring much lower neutron radiation levels than was the PNR-4 and results of these measurements verified that neutron levels were not significantly above background levels in the area.

4. "Phoswichr Detector

A Los Al amos-developed phoswich (phosphor sandwich) detector, ${ }^{6}$ which consists of a NaI crystal backed by a CsI crystal, and measures lowenergy photon radiation, such as plutonium $x$ rays, was used extensively throughout the operation to detect subsurface plutonium. The detector, electronics, and scaler were housed individually (Fig. 40). The electronics included an aural popper used when background noise levels permitted.

Because the phoswich is very sensitive to scattered radiation, it could not be used in an area housing plutonium gloveboxes and process equipment $c^{-}$in a highly zontaminated area. Once contamination levels were reduced, it became extremely useful in locating hot spots such as those in cracks or under paint on concrete floors. Phoswich readings also helped establish worker protection requirements, because below-sur face contamination levels could be estimated with some confidence. Phoswich sensitivity for painted-over plutonium is about $10,000 \mathrm{dis} / \mathrm{min}$. Its use also assured that no painted-over high-level spot was left behind. Surfaces with contaminetion detectable with the phoswich were cleaned or removed. Figures 41 and 42 show the phoswich being used for wall and ground surface surveys.

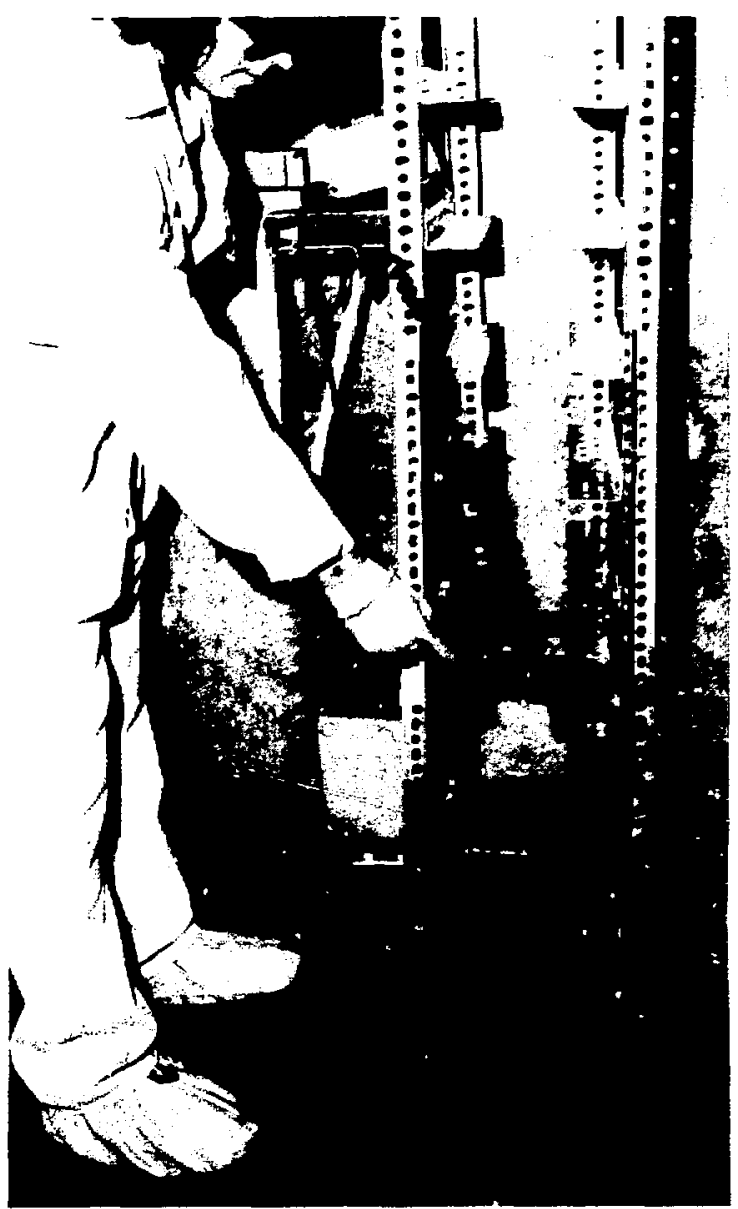

Fig. 41. Phoswich detector on rack for wall monitoring.

\section{vi. DECONTAMINATION TECHNIQUES}

Decontamination personnel performed the highlevel, high-risk glovebox and conveyor tunnel separations, and the structural decontamination requiring specialized techniques or equipment. These special decontanination techniques are described in tine rest of this section. Decontanination activities involving low-level contamination and use of conventional cleaning techniques such as washing with soap and water were performed by $2 I A$ Company personnel.

\section{A. Glovebox and Conveyor Tunnel Separation}

Although glovebox washing was not continued. experiences gained from working in and around these gloveboxes were extranely valuable and aided in accomplishing the glovebox work. 


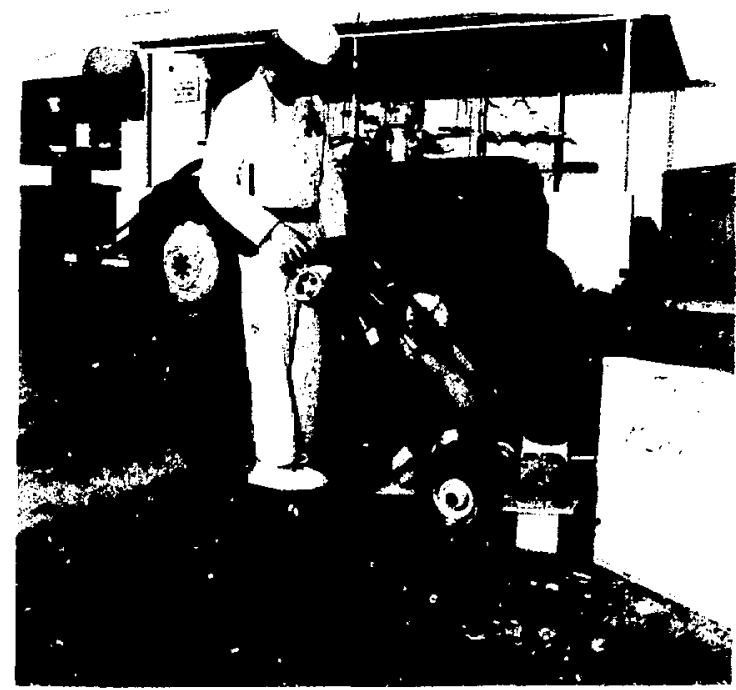

Fig. 42. Ground surface surveys with phoswicn detector.

The rationale for preparing gloveboxes and tunnels for separation was to complicate future size reduction operations as little as possible by minimizing painting, foaming, etc. After a few successful separations, cleaning and painting the separation area and the adjacent $30 \mathrm{~cm}$ in both directions became standard procedure. The lack of gloveport openings in some long sections of conveyor tunnels necessitated lowering the tunnel in one large section, fabricating an end plate that would accommodate an exhaust duct, and then separating the tunnel into smaller sections at floor level. At the selected separation point, a $15-\mathrm{cm}$ diam hole was made and decontamination and painting were accomplished with long-handled brushes and tools. The hole was later used as an exhaust port for the next separation. Support rails for the conveyor bucket did not always butt together at the separation point; hence, several tumnel sections had to be partially unbolted and separated enough to allow sawing the rails with a hacksaw blade (Fig. 43).

Glovebox separation areas were cleaned with a commercial spray detergent introduced into the glovebox system in a $1-\ell$, plastic spray bottle. After cleaning, the surface was spray-painted with enamel, also introduced in a spray container. Usually four coats of enamel were applied. The last coat was applied just before the separation.

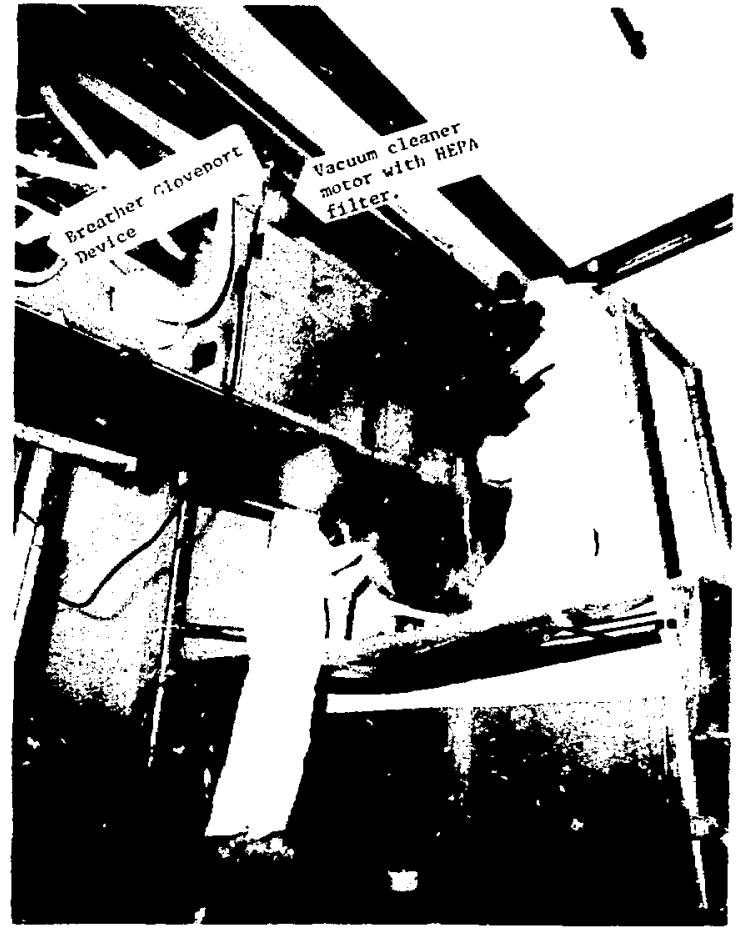

Fig. 43. Sawing of conveyor track through tunnel opening.

Large bag-out wirts were sealed by introducing a steel plate into the box, then using a bolt is tighten the external plate onto the glovebox. Silicon rubber was used as a sealant between the box surface and the plate.

The need to keep gloveboxes and conveyor tunnels under vacuum resulted in designing a gloveport vacuum device (Fig. 44) that served as an exhaust port for sections which had no connection to the process exhaust. A variac-controlled vacuum cleaner motor and a HEPA filter were used to adjust the vacuum on the box. When the box was isolated, the device then became a filtered vent for the glovebox, allowing the box to go through temperature changes during temporary storage without becoming pressurized and releasing plutonium contenination.

Almost every glovebox had a bottcm protuberance of one kind or another. Since workins safely under a glovebox was very difficult some protuberances were allowed to remain with the glovebox and were protecied by a metal rranework (Fis. 45) unich can easily be removed when the glovebox is processed at a size reduction facility. 


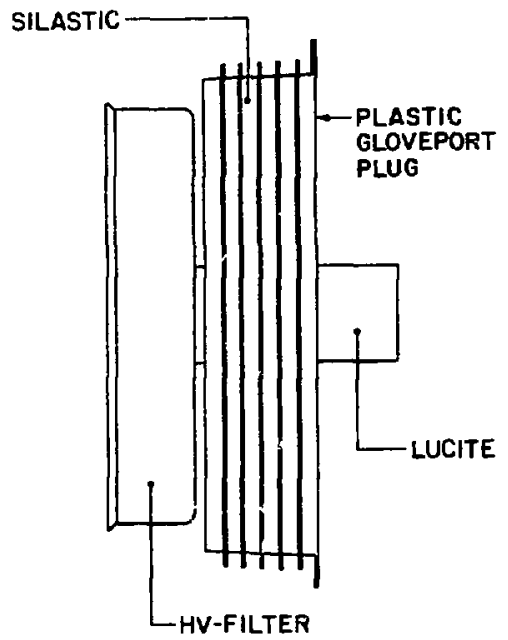

Fig. 44. Gloveport vacuum device.

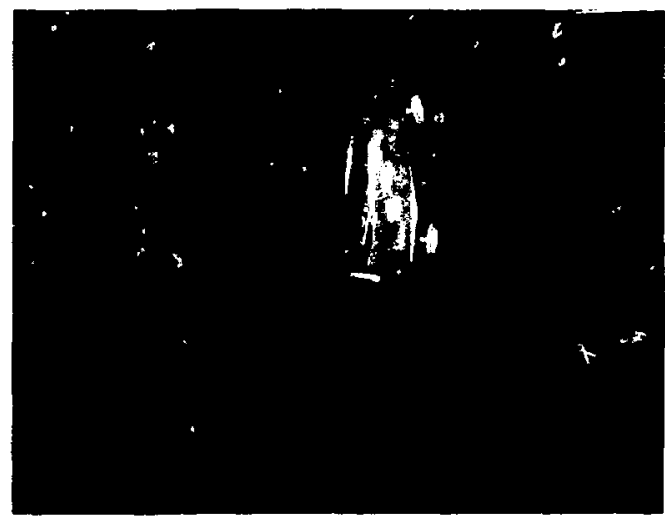

Eis. 45. Protective metal framework attached to glovebox bottom.

\section{B. Concrete Surf?ces}

The project required decontamination of 5300 $\mathrm{m}^{2}$ of concrete slab floors. Since Los $\mathrm{Alamos}$ experience was primarily $11 \mathrm{mit} \in \mathrm{d}$ to using acids, paint removers, and pneumatic chippers on small areas, new techniques had to be developed for large areas.

Early in the project single-head, hand-held and seven-head, floor-type pneumatic scarifying tools were purchased and experimentation began in isolated areas. To el iminate the possible spread of contamination, an enclosed HEPA-filtered con-

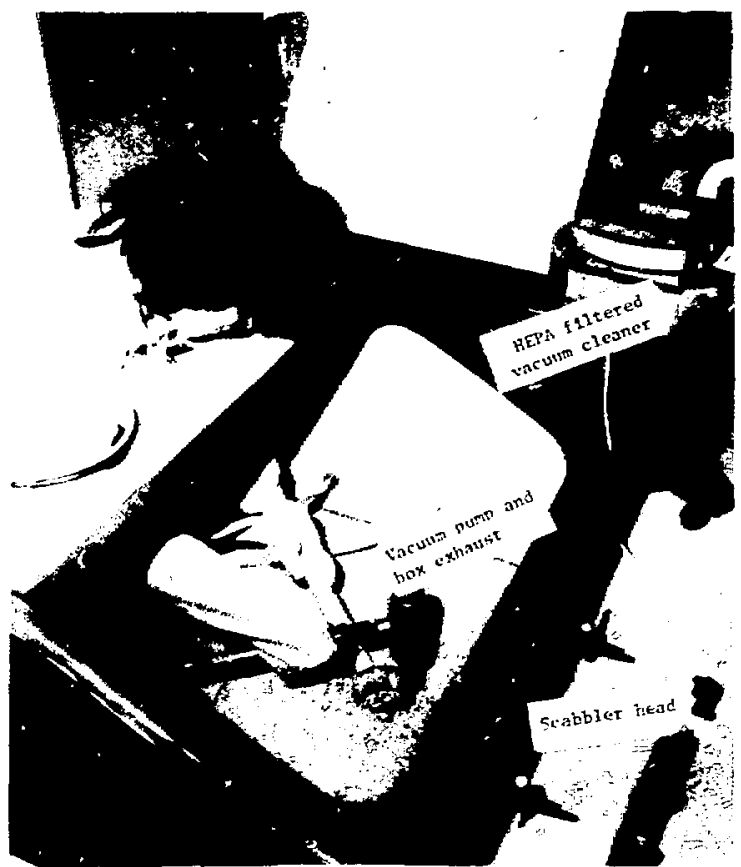

Fig. 46. Confinement chamber for scarifying.

finement chamber was constructed using a glovebox section (Fig 46).

Munerous tests were conducted with a floortype scarifier. By covering the floor with a thin layer of water or water-detergent mixture and vacuuming immediately after scarifying, very high levels of plutonium contanination could be scarified without spreading contamination or creating an airborne problem (Fig. 47). This method was used to decontaminate over $3500 \mathrm{~m}^{2}$ of concrete surfaces.

The erfectiveness of scarifying was compared to using abrasives, acid solutions, and paint removers. Scarifying proved to be the safest and most cost effective. ${ }^{7}$ Identifying highly contaminated areas with the phoswich detector, scarifying them, then scarifying the entire floor using the floor model soon became standard prastice. Each pass removed approximately $0.5 \mathrm{~cm}$. Usually, except for cracks or bolt holes, two or three passes removed all contanination. Renoval of bolt pluss or anchors used for supporting gloveboxes and other equipment required resoval with $a$ hand-held air chisel. Room 213 in Building 2, for exemple, had 600 bolt plugs and anchors. Sone 125 m of metal 


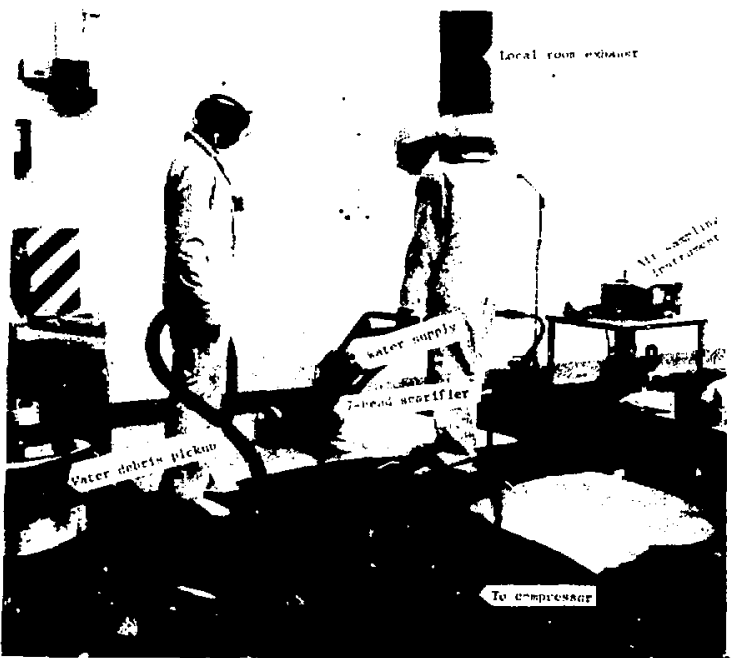

Fig. 47. Removal of concrete surtace.

stripping used to cover expansion joints in the concrete flcors were also removed. The ends were loosened with a pneumatic chisel and pried loose with a crowbar. The remaining cracks were usually highly contaninated; hence, they were spray painted and cleaned with a hand-held scarifier after strip removal.

The single-head scarifier was used on some of the concrete stub walls. Although using a singlehead model was time consuming. it was effective and met all the needs of this project. By keeping the surface wet. scarifying could be done without airborne contamination problems.

\section{Metal Surfaces}

Decontaminating metal structural supports, wa: I sheeting, etc.., depended on contamination, finish (painted us unpainted), and the value of the item.

Structural supports in relatively clean areas such as atlics were damp mopped or wiped using water and detergent solution. Metal wall part1tions with fixed contamination vere decontaminated when possible by using paint removers or dilute HC 1 solutions with abrasive cleaners. Generally, for fixed contamination, detergents were ineffective, paint remover somewhat effective, and HC1 solutions and abrasives very effective, renoving approximately $80 \%$ of the contamination. Higtily contaminated walls were renoved to save time and costs, to be more complete, and to minimize injuries such as acid burns, cut fingers, etc.

\section{Plaster Walls and Ceilings}

Most wall surfaces were piaster on metal lath Early in the project, paint remover was used to try to save the plaster, but the many steps required to apply the remover, serape it off, check the surfaces, and then repeat this process several times made it easier and more economical to remove and replace the plaster. Paint was removed from a total of $270 \mathrm{~m}^{2}$ of wall surface and $427 \mathrm{~m}^{2}$ of plaster were renoved.

A very useful contamination control aid used while scarifying or chipping contaminated plaster and paint was a filtered vacuum cleaning system which could be positioned to collect chips and dust from the operation. The 200- (55-gal) drum which served as a trap was later sealed and used as the primary waste disposal container (Fig. 48). The vacuum cleaner was a commercially available, air operated, HEPA-filtered system.

\section{WASTE MANAGEMENT}

Waste management aspects of the operation were directed by an onsite representative from the Laboratory's Waste Management Group, H-7.

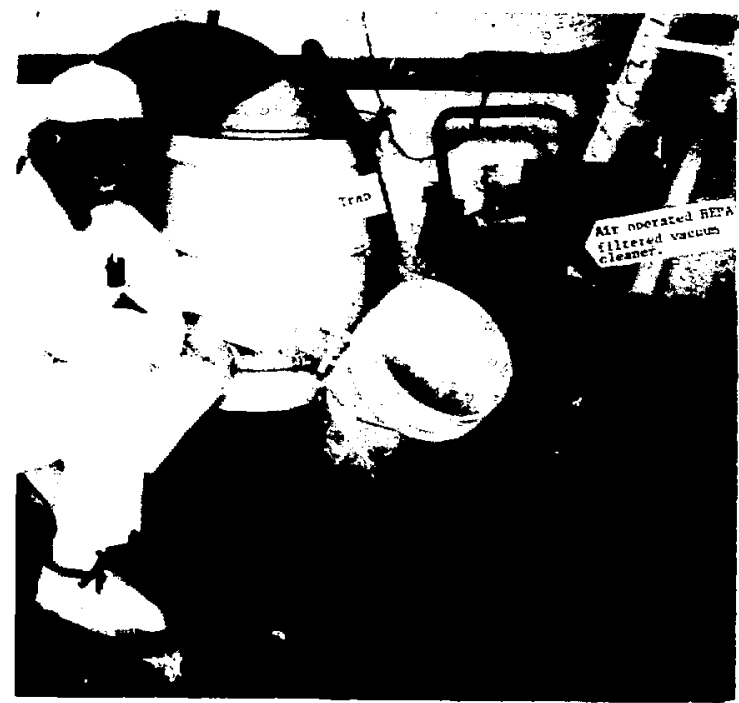

Fig. 48. Device used to collect plaster and paint chips. 
When practical, ruvil trash was packaged in $0.05-\mathrm{m}^{3}$ cardboard boxes and surveyed for retrievability in a Multiple Energy Gamma Assay System counter ${ }^{8}$ (Fig. 49). Nonretrievable waste totaling $7426 \mathrm{~m}^{3}$ was sent to $\mathrm{Ti}-54 \mathrm{in}$ plastic-1ined, tarpaulin-covered trucks or Dempster Dumpster waste containers.

Waste with over iG $\mathrm{nCi}{ }^{239} \mathrm{Pu}$ or $100 \mathrm{nCi}{ }^{238} \mathrm{Pu}$ per gram of waste was packaged and $\mathrm{placed}$ in approved TRU storage containers and trucked to TA-54. Retrievable waste generated by this operation consisted of $1488 \mathrm{~m}^{3}$ of gloveboxes and conveyor tun nels (Fiz. 50); $166 \mathrm{~m}^{3}$ of pipe, duct, etc, (Fig. 51); and $104 \mathrm{~m}^{3}$ of soil.

One hundred and two cutic meters of gloveboxes packaged in bolted metal containers were sent to TA-50-37 for ruture size reduction studies.

Each load of waste sent to Th-54 for disposal or storage was accompanied by a Laboratory Radioactive Solid Waste Dispos? Record Form. ${ }^{2}$

Liquid wastes were treated at an on-site industrial waste treatment plant. ${ }^{9}$ Before removing of the acid wells, liquids were poured down the dratns located in the janitor closets in each building. With the removal of the acid wells and associated piping. Iiquids were vacuumed into 200-? (55-gal) drums and later pumped into a 2000-

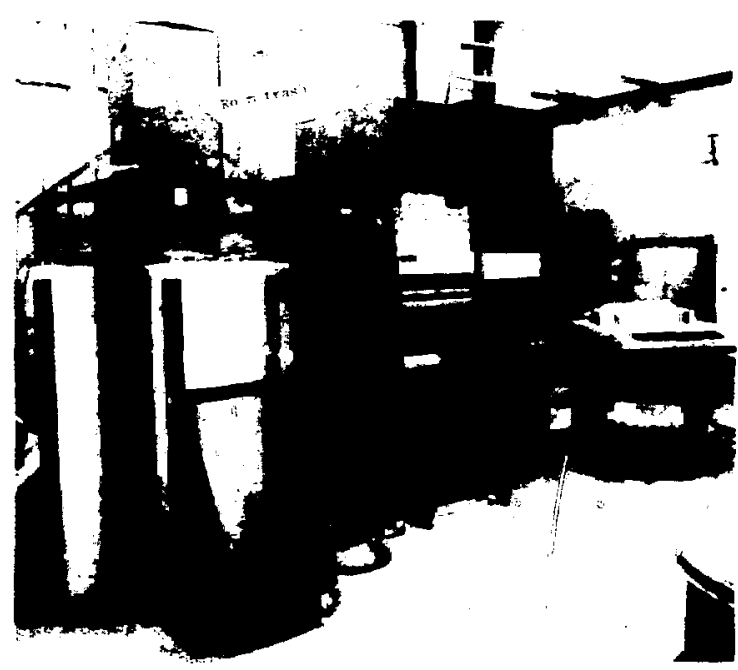

Fig. 49. Multi Energy Gamma Assay Systen. (500-gal) trailer, for delivery to the treatment plant. Solutions from the glovebox washing operations were vacuumed into a $20-l \quad c y l i n d e r$ and analyzed for plutonium before pumping to the trailer.

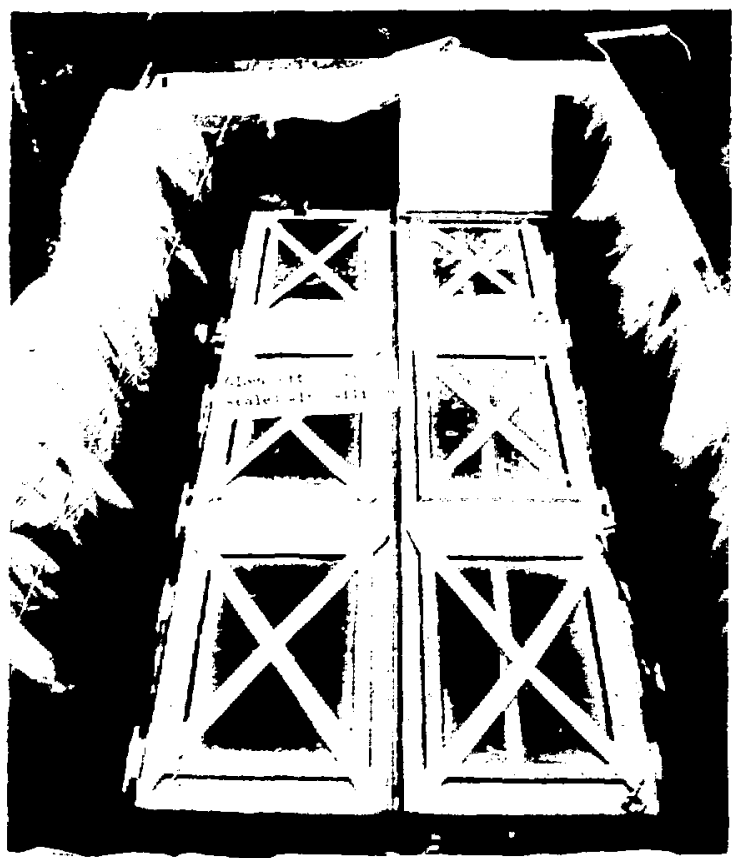

Fig. 50. Glovebox secticn in 20-year storage container.

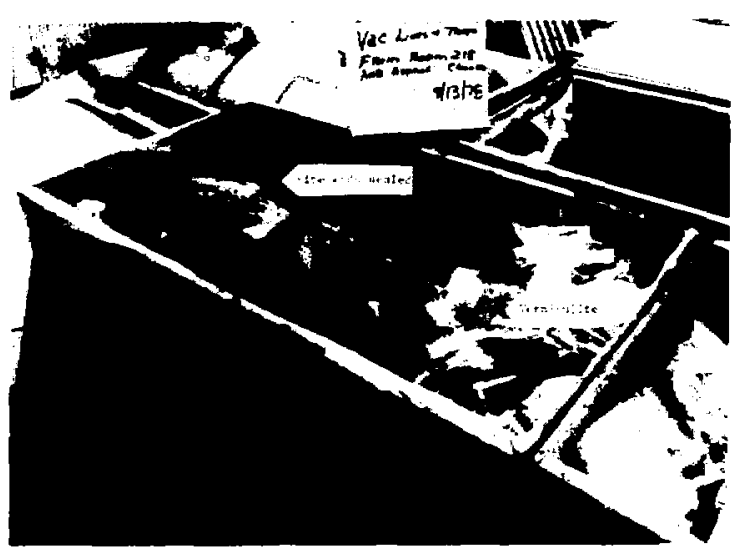

Fig. 51. Twenty-year storage container with aiscelIeneous pipe. 
vIII. $\cos T S$

The project required three years and a total cost of $\$ 4,418,400$. Table I lllustrates the craft application and time required to accomplish this task. Health physics personnel time as shown in the table covers final surveys only. Table II lists the costs for each of the participating organizations and supplies.

\section{ACKMONLEDGEHENTS}

Many Los Alamos National Laboratory and $z i a$ Company personnel contributed to the success of this decontamination effort. However, the authors are particularly grateful to John Anderson, CMB-11, for controlling the budget and providing advice and key CMB-11 support per sonnel as necessary; Charles Bl ackwell, $H-1$, for handling the project's records and waste management problems; Pascual Chavez, $\mathrm{H}-1$, for ensuring that work crews didn't lack health physics monitoring support, and that areas were surveyed for timely release to new occupants; Al fredo B. Fernandez, H-1, for converting unskilled new hires inte effective radiation workers in a manner that the glovebox separations remained on schedule; Robert Gilmore, CMB-11, for helping establish initial glovebox and tunnel separation techniques; Darrell P. Hohner, ENG-1, for his effective advance $\mathrm{pl}$ anning and foresight; and Mike Tomlison, 2ia company, for his effective supervision of 21 a crafts personnel. The assistance received from Joyce Martinez, $\mathrm{H}-1$, in preparing the document and from Frank Lavigne, Zia, in providing the drawings are also appreclated.
TABLE II

SUMMARY OF COSTS FOR THE DP HEST PLUTONILM DECONTAMINATION PROJECT

\begin{tabular}{|c|c|c|c|c|c|c|}
\hline & 1977 & 1978 & $\begin{array}{l}\text { Costs } \\
1979\end{array}$ & $\begin{array}{l}3 \text { in Tho } \\
1980\end{array}$ & $\begin{array}{c}\text { dsands of } \\
1981\end{array}$ & $\begin{array}{l}\text { Is } \\
\text { TOThL }\end{array}$ \\
\hline \multicolumn{7}{|c|}{ IOS ALAMOS WATTOHAL LABOAATOAY } \\
\hline $\begin{array}{l}\text { H-Division } \\
\text { CHB-DIVIsion } \\
\text { EHG. WX, E }\end{array}$ & $\begin{array}{l}1.3 \\
0.0 \\
0.0\end{array}$ & $\begin{array}{r}148.5 \\
43.5 \\
1.7\end{array}$ & $\begin{array}{r}473.6 \\
164.4 \\
68.2\end{array}$ & $\begin{array}{r}416.1 \\
180.3 \\
62.3\end{array}$ & $\begin{array}{r}93.0 \\
5.9 \\
1.4\end{array}$ & $\begin{array}{r}1132.5 \\
.394 .1 \\
133.6\end{array}$ \\
\hline 2IA COHPANY & 0.0 & 144.8 & 767.9 & 1190.4 & 110.7 & 2213.6 \\
\hline $\begin{array}{l}\text { HATERIAL } \\
\text { General Supplies } \\
\text { Fiber } r_{1} \text { lass Boxes }\end{array}$ & $\begin{array}{r}19.7 \\
0.0\end{array}$ & $\begin{array}{r}55.7 \\
0.0\end{array}$ & $\begin{array}{l}66.7 \\
98.8\end{array}$ & $\begin{array}{r}50.6 \\
169.1\end{array}$ & $\begin{array}{l}63.2 \\
20.6\end{array}$ & $\begin{array}{l}255.9 \\
288.5\end{array}$ \\
\hline Totals & 21.0 & 394.2 & 1639.6 & 2068.8 & 294.8 & 4518.4 \\
\hline
\end{tabular}

\section{REFERENCES}

1. "Management Plan for TA-21, DP iest, Group CMB-11, Plutoni um Facilities" (October 1979), internal document.

2. Los Mlamos Scientific Laboratory Health. Safety and Enviroment Manual, Chap. 1, Sec. 7: Waste Disposal (1979).

3. E. L. Christensen, R. Garde, A. M. Valentine, "Demolition of Building 12, An old Plutonium Filter Building," Los Alamos Scientific Laboratory report LA-5755 (January 1975).

4. D. Vasilik, "Plutonilm Wound Procedures, Revision. May 3, 1979," Los Al amos internal memorandum.

5. J. N. P. Lawrence, "Plutonium Urine \& Fecal Sampling." Los Alamos Scientific Laboratory report LA-3836 SOP Rev (JuIy 1973).

6. C. J. Umbarger and M. A. Wolf, "A Battery Operated Portable Phoswich Detector For Field Monftoring of Low Levels of Transuranic Contaminates," Nuc. Instruments and Methods 155. $453-457(1978)$.

7. E. J. Cox and Ray Garde, "Decontamination of Concrete Surfaces at the Los Alamos Scientific Laboratory." Proc. Concrete Decontanination Workshop, Seattle, Washington, DOE, 109-23 (1980).

8. C. J. Unbarger and L. R. Couder, "Heasurements of Transuranic Solid Waste at the $10 \mathrm{nC1} / \mathrm{s}$ Activity Level," Nuc. Tech. 27, 500 (November 1975).

9. C. W. Christenson and L. A. Emelity, "Chealical Treatment and Cenent Fixation of Radloactive Waste," Journal Water Pollution Control Federation, 1343-1350 (July 1970). 


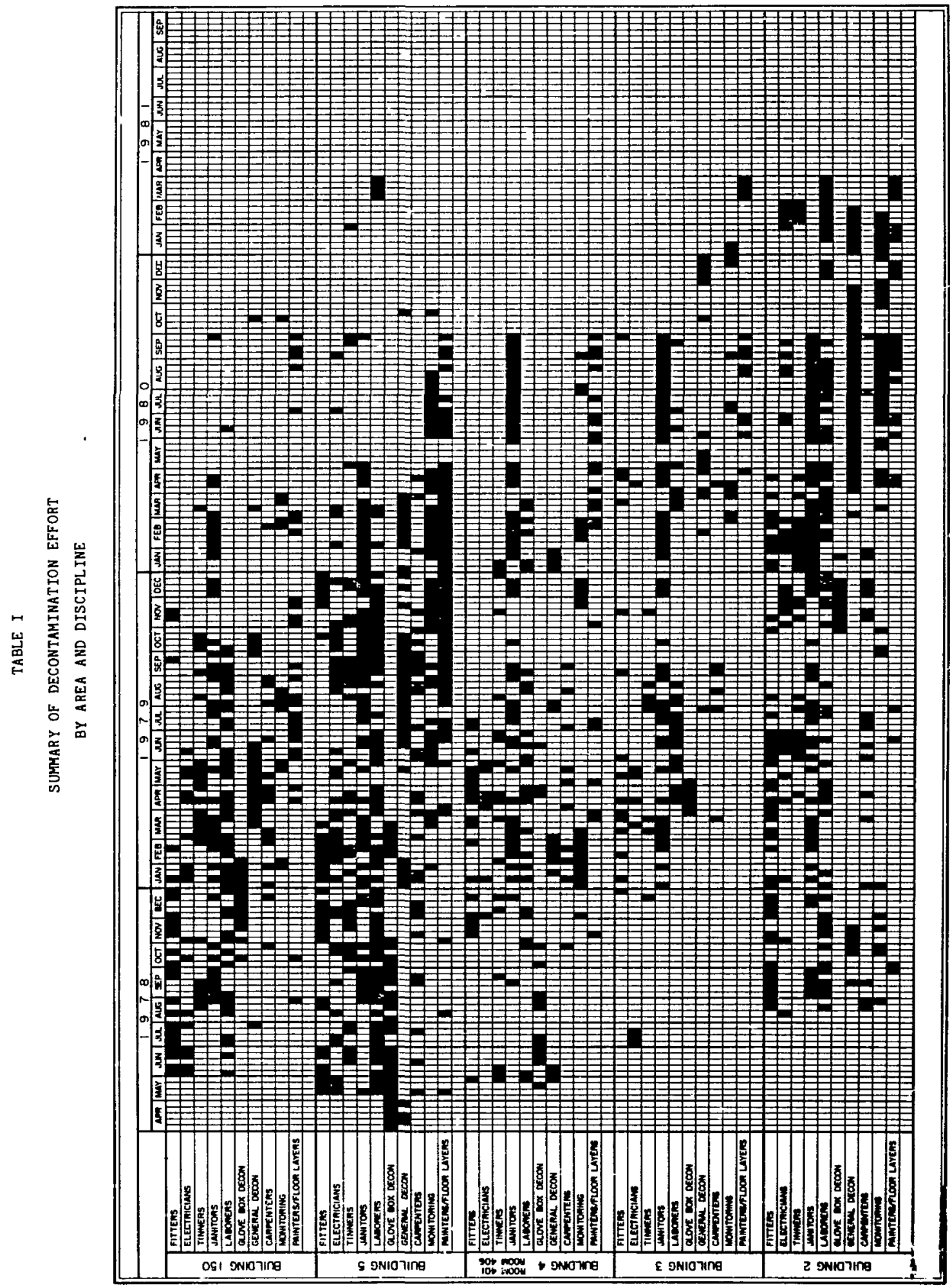


APPENDIX A

GLOVEBOX ACID WASH PROCEDURE

Washing a glovebox requires a minimum crew of two decontamination technicians and a health physics technician.

Preparation

1. Make sure the crafts have completed disconnecting the ut1lities and the tinner craftsmen have installed flex duct and an in-line filter in the exhaust system.

2. Check the glovebox vacuum; it should be at least $1 / 2$ in of $\mathrm{H}_{2} \mathrm{O}$, when measured by a magnehelic gauge.

3. Prepare area: remove loose 1 tems from around the glovebox, clean area, lay plastic sheeting on the floor and surrounding surfaces.

4. Isolate area with barriers and signs.

5. Establish monitoring station at entrance. Equip with hand-foot counter, clean booties, spare coveralls, rubber gloves, etc.

6. Position equipment, check operation of pump and vacuum system.

7. Drill two 1/2-inch holes into face of glovebox, insert approximately $1.5 \mathrm{~m}$ of plastic tubing into box and epoxy in place.

8. Bag epoxy andior silastic sealants into glovebor.

9. Seal all openings, 1.e., bag-out port covers, furnace covers, etc.

10. Allow epoxy or silastic time to set; overnight should be adequate.
Acid Wash

1. Hix acid solution, $203 \mathrm{HNO}_{3}-33 \mathrm{HF}$, in a ventilated hood. Transport to work area in a capped plastic carboy.

2. Transfer 3 or 4 liters of acid solution into pump reservoir.

3. Activate pump and spray interior of box startIng at the top. Pay particular attention to window gaskets. When wash cycle is completed, let solution drain down the sides and collect on the bottom. Allow 20-30 minutes. Record amount of acid solution used.

4. Vacuum out as much acio solution as practical.

5. Add tap water to pump reservoir and spray interior of box. Record amount of water used.

6. Vacuun out water.

7. Repeat steps 2 thru 6, two times.

8. When vacuum holding tanks are full, draw a 2-me sample and submit to $H-7$ for analysis. on analysis request form indicate total amount of solution represented by sample.

9. Change glovebox gloves for NaI survey (number and location of gloves to be changed will be determined by survey analyst). During change. bag out old gloves and epoxy containers. Cut off exposed ends of wash and vacuum tubes and seal ends.

10. After NaI survey, Install plastic gloveport plugs.

\section{APPENDIX B}

DETERMINING RESIDUAL PLUTONIUM IN GLOVEBOXES

USING NaI DETECTION SYSTEM

\section{INTRODUCTION}

This technique uses an NaI scintillation detector for detecting the low-energy photons emitted during the decay of the transuranic radionuclides. For plutonium essay, the decay of $x$ rays (energies approxinately $17 \mathrm{keV}$ ) are monitored. For ${ }^{241} \mathrm{Nm}$ the decay 60-keV gama ray is detected.
The entire system remains external of the glovebox and measurenents are made by placing the probe into a clean unleaded glove and aining it at the surface of interest. Photon transission through the glove is better than $70 \%$ for photon energies above 15 keV. 
The electronics package consists of a photomultiplier tube base and preamplifier, a highvoltage power supply, and a Davidson Model 1056 multichannel analyzer.

\section{PROCEDURE}

- Prepare a map of the glovebox showing dimensions with actual measurements, determine where clean gloves are needed to allow monitor Ing without significant overlapping. $\pm 10 \%$ of actual surface area.

- The Model 1056 analyzer has easily set "Reglons of Interest" (ROI) for integrating peaks or other groups of channels. Up to eight spectra of 128 channels each may be held in separate memory subgroups, allowing comparison between measurements and the holding of data for later transcription. Spectra are shown on the small display scope. Set six ROI, one for each set of channels 4-8, 10-25, 27-31, 39-43, 45-60, 71-75. In all eight of the 128-channel memories.

- An $8.54 \mathrm{Ci}{ }^{241} \mathrm{Am}$ source is used for calibration. The display scope will show two peaks, one centered near channel 17 and covered by the chanel 10-25 ROI, the other centered near channel 60 and covered by the channel 45-69 ROI. Further, the counts in the 45-69 ROI should be roughly equal ( $\pm 10 \%)$ with the 10-25 ROI slightly higher. The gain on the Model 1056 will occasionally need to be changed to center the 17and 60-keV peaks.

- From map, determine location and probe to surface distance. Perform a 10-second count, at each location, repeat unt1l all efght memory channels have been used. Record counts for each channel, erase, and continue unt1l all locations have been surveyed.

- Survey location and counts obtained are transferred to an $80-c o l u m n$ entry form and submitted to the Laboratory computer Center. The final results will be in $\mathrm{nc1} / \mathrm{cm}^{2}$. Th1s number is then multiplied by 5 or 9 depending on the extent of decontanination the box received prior to the survey.

- Final $n C 1 / g$ values are obtained by applying the $\mathrm{nCl} / \mathrm{cm}^{2}$ value to the glovebox surface area and weight. 